\title{
MULTIPLE REGIME SHIFTS IN A SUBTROPICAL PEATLAND: COMMUNITY-SPECIFIC THRESHOLDS TO EUTROPHICATION
}

\author{
Scot E. Hagerthey,${ }^{1,4}$ Susan Newman,,${ }^{1}$ Ken Rutchey, ${ }^{1}$ Eric P. Smith, ${ }^{2}$ and Jason Godin ${ }^{3}$ \\ ${ }^{1}$ Everglades Division, South Florida Water Management District, 3301 Gun Club Road, West Palm Beach, Florida 33406 USA \\ ${ }^{2}$ Department of Statistics, Virginia Tech, 211 Hutcheson Hall, Blacksburg, Virginia 24061 USA \\ ${ }^{3}$ Water Supply Department, South Florida Water Management District, 3301 Gun Club Road, West Palm Beach, Florida 33406 USA
}

\begin{abstract}
Ecosystems have a natural resilience to perturbations, where resilience is the magnitude of a disturbance that an ecosystem can resist before changes in structure, function, and services result in a regime shift. The Everglades region of Florida, USA, has been detrimentally impacted by phosphorus $(\mathrm{P})$ enrichment and a regime shift from Cladium (sawgrass) to Typha (cattail) marsh has been described. We examine another facet of the lownutrient Everglades stability regime, open-water sloughs, to determine if eutrophication leads to similar regime shifts.

We analyzed surface water $\mathrm{P}$ and soil $\mathrm{P}$ as controlling variables that, once a critical threshold is surpassed, alter ecosystem state variables. Nonlinear relationships between $\mathrm{P}$ and vegetation were observed along a northern Everglades eutrophication gradient. In addition to the Cladium-Typha regime shift, a second independent regime shift, slough-Typha, was identified. Synoptic surveys of 49 sloughs within the boundary between the slough and Typha regime revealed that surface water total phosphorus (TP) and the benthic algal floc layer (BAFL) were the controlling variables, with critical thresholds of $11 \mu \mathrm{g} / \mathrm{L}$ and $412 \mathrm{mg} / \mathrm{kg}$, respectively. The slough regime below these thresholds was characterized by calcareous periphyton $(\mathrm{BAFL} \mathrm{TP}=298 \mathrm{mg} \mathrm{P} / \mathrm{kg}$; BAFL calcium $=149 \mathrm{~g} \mathrm{Ca} / \mathrm{kg}$ ). Above the TP thresholds, vegetation composition shifted to open-marsh species with significantly higher BAFL TP $(700 \mathrm{mg} \mathrm{P} / \mathrm{kg})$ and total organic carbon (TOC) $(350 \mathrm{~g} \mathrm{C} / \mathrm{kg})$. A second BAFL TP threshold occurred at $712 \mathrm{mg} \mathrm{P} / \mathrm{kg}$, above which Nymphaea dominated and BAFL TP (1034 $\mathrm{mg} \mathrm{P} / \mathrm{kg}$ ) and TOC ( $417 \mathrm{~g} \mathrm{C} / \mathrm{kg}$ ) significantly increased. Nymphaea sloughs transitioned to the Typha regime. The boundary reflects the loss of ecosystem resilience due to eutrophication. Both low-nutrient stability regimes (slough and Cladium) lie precariously close to the $\mathrm{P}$ critical threshold but differ in how eutrophication is absorbed and resisted. The slough regime transitions rapidly through a series of ecosystem state changes linked to positive feedback loops that affect $\mathrm{P}$ dynamics, whereas the Cladium regime does not. An adaptive management strategy has been implemented to address the surface water TP threshold; however, to ensure successful restoration of the Everglades, the BAFL and soil TP thresholds also need to be considered.
\end{abstract}

Key words: change point; Cladium jamaicense; Everglades, Florida, USA; feedback loops; nutrient gradient; peat soils; phosphorus threshold; regime shift; slough; Typha domingensis.

\section{INTRODUCTION}

Regime shifts are seemingly sudden or abrupt changes in ecosystem structure, function, and services and have been observed for a variety of ecosystems (Scheffer and Carpenter 2003, Folke et al. 2004, Walker and Meyers 2004). Regime shifts are analogous to alternate stable states, but include both the intrinsic generated dynamics and external forces that regulate natural fluctuations within a regime (Scheffer and Carpenter 2003). Shifts occur when feedbacks change as the critical threshold of a controlling variable is surpassed, ultimately resulting in changes in the ecosystem's state variables (Walker and Meyers 2004). Ecosystems do have a natural resilience to perturbations (ecosystem resilience) that

Manuscript received 2 April 2007; revised 20 December 2007; accepted 28 January 2008. Corresponding Editor: C. R. Hupp.

${ }^{4}$ E-mail: shagerth@sfwmd.gov enables them to absorb disturbances without any significant changes to structure or function (Holling 1973, Gunderson and Pritchard 2002). However, certain types of disturbances (e.g., eutrophication) can slowly erode ecosystem resilience, essentially moving the regime closer to the critical threshold and thereby making it more likely that a regime shift will occur (Folke et al. 2004, Carpenter 2005).

To sustain or restore a desired ecosystem state, an adaptive management approach geared toward resilience is required (Folke et al. 2004). Maintaining the desired state could be accomplished by moving the controlling variable away from the critical threshold. Restoring a desired ecosystem, however, may be more difficult because of hysteresis effects, which may require moving the controlling variable toward and beyond the critical threshold (Folke et al. 2004, Groffman et al. 2006). In some cases, restoration may be unattainable 


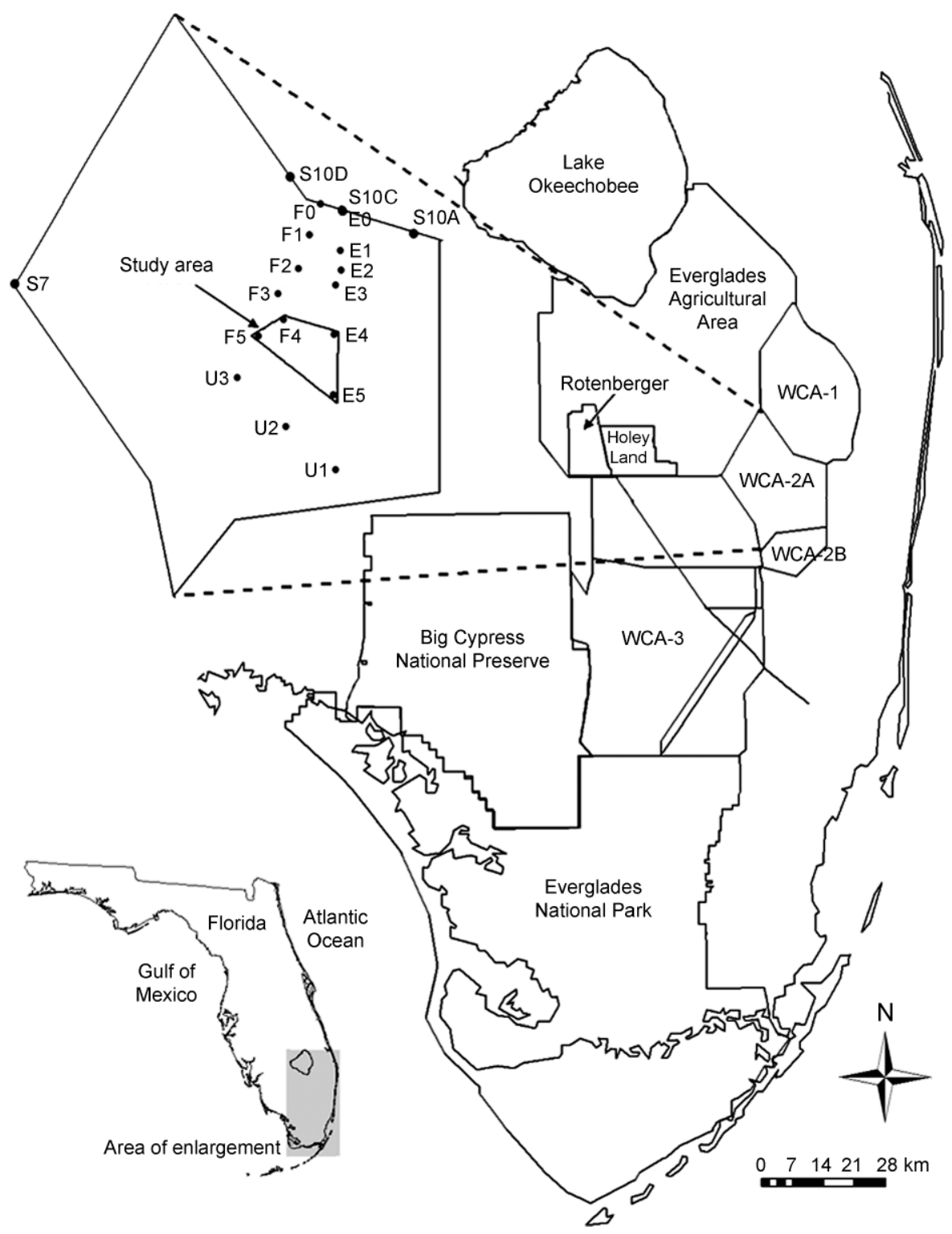

FIG. 1. The location of the Water Conservation Area-2A (WCA-2A) impoundment within the Everglades ecosystem. Regime shifts were studied using the 13 monitoring sites labeled E, F, and U. F0 and E0 are located in the L-39 canal. L-39 canal water enters WCA-2A through the S10-A, S10-C, and S10-D gravity control structures. The slough-Typha regime shift boundary was studied in greater detail in the $12.3-\mathrm{km}^{2}$ area (polygon) demarked by sites F4, E4, F5, and E5.

(Folke et al. 2004, Carpenter 2005). Nonetheless, governance of resilience requires a complete description of the threshold, including the controlling variables, the state variables that change as the threshold is surpassed, and the processes responsible for the change (Walker and Meyers 2004, Groffman et al. 2006). Folke et al. (2004) further suggest four similar critical attributes: (1) latitude, how much can be absorbed before a regime shift occurs; (2) resistance, the ease which a regime shift is brought about; (3) precariousness, how close the current trajectory is to the threshold; and (4) cross-scale relations, how the dynamics of systems above and below the scale of interest affects the aforementioned three attributes.

The Everglades is a large, oligotrophic subtropical wetland (Fig. 1) whose historical nutrient inputs were primarily provided via atmospheric deposition. Within the last century, anthropogenic disturbance associated with water management, agricultural practices, and urbanization has resulted in increased nutrient loading, primarily phosphorus $(\mathrm{P})$, and alterations of natural hydro-patterns (Davis and Ogden 1994, Porter and Porter 2002, Sklar et al. 2005). Gunderson (2001) describes a regime shift from a low-nutrient sawgrass 


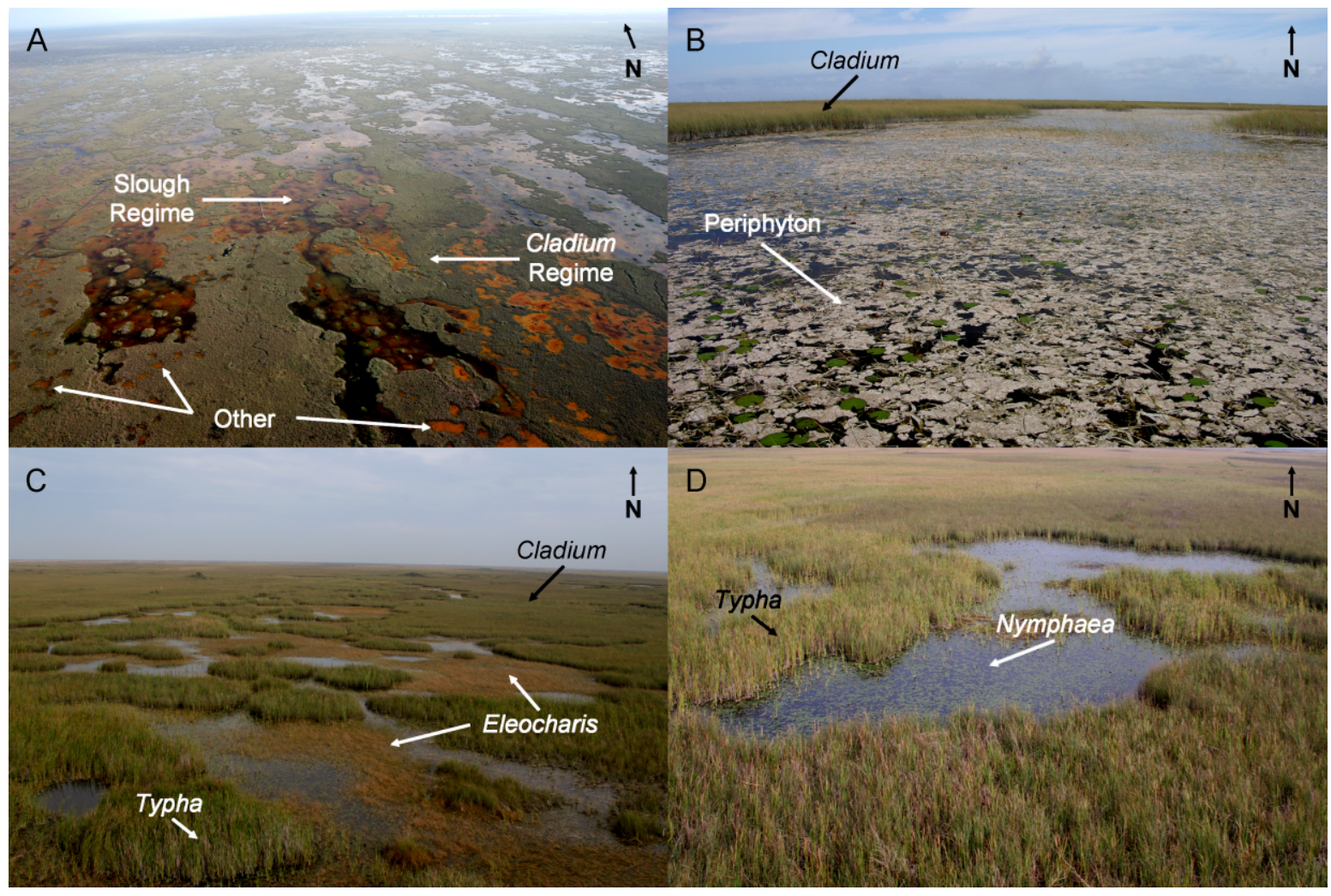

FIG. 2. Representative photographs of sloughs and the vegetation therein in WCA-2A classified as (A) "other," (B) periphyton, (C) open marsh, and (D) Nymphaea. Also shown in panel A are the slough and Cladium communities representative of the lownutrient stability regime. Photo credits: S. Hagerthey.

(Cladium jamaicense Crantz) regime to one dominated by cattail (Typha domingensis Pers.). The low-nutrient stability regime consists of a matrix of Cladium and wet prairie maintained by interactions among fire, drought, and freezes. Increases in soil P caused by discharges of P-rich surface waters have reduced the resilience of the low-nutrient Cladium regime. When this low-resilience regime is subjected to a disturbance such as fire, drought, or freezes (i.e., triggers), Cladium is competitively displaced by Typha, resulting in an alternative high-nutrient stability regime. The extent of the Typha regime is best illustrated in Water Conservation Area2A (WCA-2A), an impounded northern Everglades marsh (Fig. 1; see Plate 1). The total area of monotypic Typha increased from 442 ha in 1991 to 1979 ha in 2003, a 469\% increase in areal extent (Rutchey et al., in press). Similar, but less dramatic in areal extent, shifts have been observed throughout the Everglades (Childers et al. 2003).

Gunderson (2001) recognized that the low-nutrient stability regime was characterized by two community types, Cladium and wet prairie; however, focus was given only to the response of Cladium to eutrophication and the subsequent shift to a high-nutrient stability regime dominated by Typha. Yet wet prairies and sloughs are common in the current Everglades landscape
(Fig. 2A; see Plate 1), comprising $14 \%$ and $27 \%$ of WCA-2A and WCA-3, respectively (Rutchey et al. 2005; Rutchey et al., in press). Water depths in both are greater than in adjacent Cladium ridges. Wet prairies are typically characterized by short-stature emergent vegetation (Eleocharis spp., Cladium, or Panicum spp.), whereas sloughs have floating emergent vegetation such as the fragrant water lily Nymphaea odorata (Rutchey et al. 2005). Periphyton and submersed aquatic vegetation, mostly Utricularia spp., are also common to both; hereafter, we use the term "slough" to represent both wet prairies and sloughs.

There is substantial evidence to suggest that the response of sloughs to eutrophication is spatially distinct and independent of Cladium eutrophication. The changes in Everglades' slough structure and function associated with eutrophication are well documented along gradients downstream of point source discharges (see reviews by McCormick et al. 2002, Sklar et al. 2005). One key result was the identification of the controlling variable $(\mathrm{P})$ and establishment of the five-year geometric mean total P (GMTP) concentration of $10 \mu \mathrm{g} / \mathrm{L}$ as the critical threshold (The State of Florida Class III water quality criterion, Florida Statute Chapter 62-302.540). Above $10 \mu \mathrm{g}$ GMTP/L, an imbalance in natural flora and fauna occurs, as reflected in losses of native 


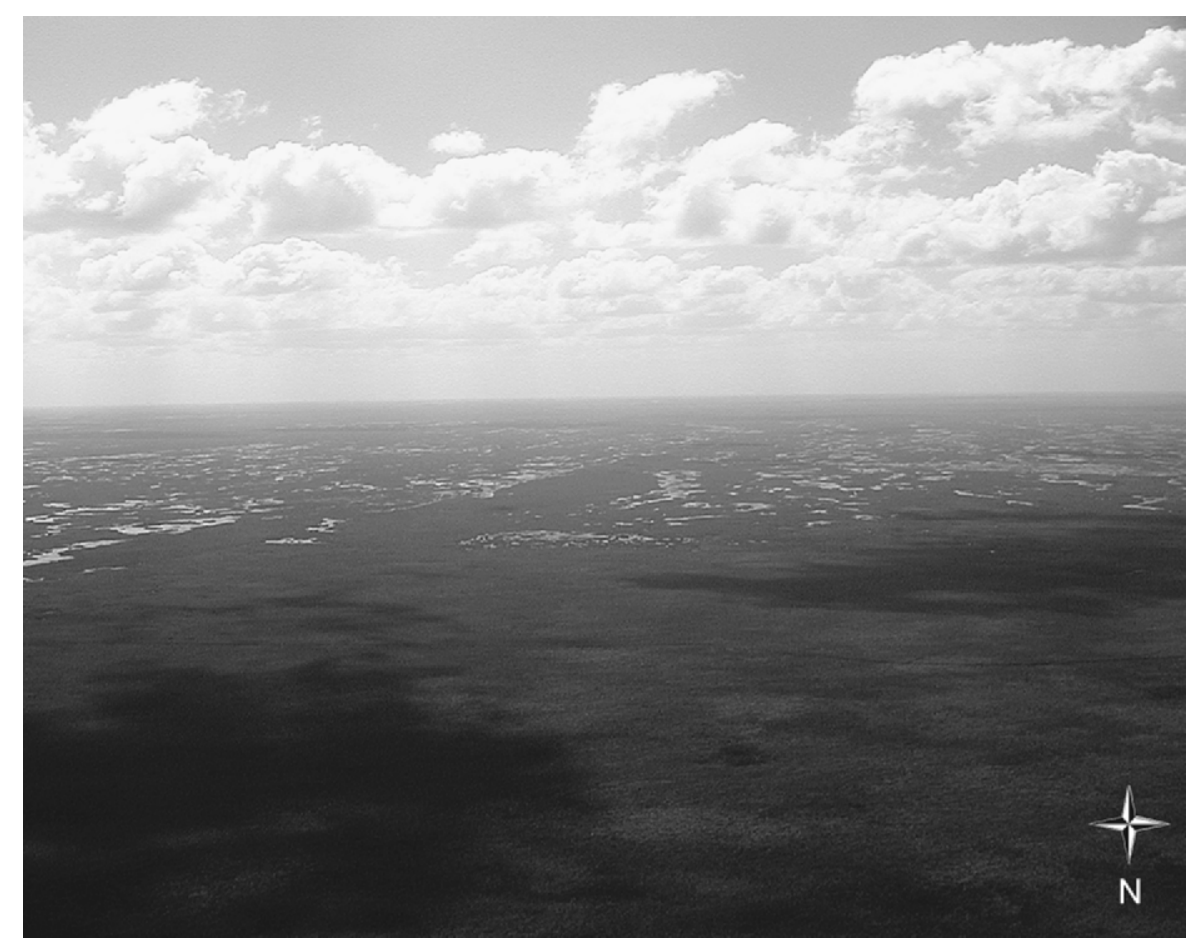

Plate 1. Aerial photograph of the abrupt transition between the low-nutrient slough regime and the high-nutrient Typha regime (foreground) in Water Conservation Area-2A, Everglades, Florida, USA. Photo credit: S. Hagerthey.

periphyton and invertebrate assemblages, decreases in ecosystem metabolism, and increases in plant species composition and nutrient content (McCormick et al. 2002, Sklar et al. 2005). Within WCA-2A, these ecological changes occur abruptly in a region Sklar et al. (2005) referred to as the "zone of community change."

The objective of this study is threefold. First, we examine the nutrient gradient extending from discharge structures into the WCA-2A marsh interior in the context of regime shifts. We focus on surface water GMTP and soil TP as controlling variables and dominant communities (slough, Cladium, and Typha) as state variables that might change if a threshold in the controlling variables is surpassed. Second, we perform a more detailed description of the boundary between the low-nutrient slough regime and the high-nutrient Typha regime. We accomplish this by (1) assessing the spatial distribution of surface water GMTP and nutrient content of two soil fractions, a surficial layer consisting either of benthic algae or floc, and $0-10 \mathrm{~cm}$ of consolidated soil; (2) assessing community structure (GIS classification of slough vegetation and Nymphaea odorata nutrient content); (3) determining if critical thresholds exist between surface water GMTP and soil TP and community structure. Finally, we develop a conceptual model that links the observed patterns in ecosystem structure with processes that most likely influence change during the shift from the low-nutrient to high-nutrient stability regime.

\section{Methods}

\section{Study site}

The study was conducted within WCA-2A, a 44807ha impounded marsh in the northern Everglades (Fig. 1). Impoundment began in the early 1950s with the construction of canals and levees designed to provide flood control and protection to eastern urban areas and the western Everglades Agricultural Area, EAA (Light and Dineen 1994). These features altered the hydrology of WCA-2A. Eutrophication began in the early 1960s with the completion of the S-10A, C, and D gravity control structures and the S-7 pump station. For the periods of 1979-1993 and 1994-2004, yearly P loading from these structures averaged 79 and $57 \mathrm{Mg} \mathrm{P} / \mathrm{yr}$, respectively (1 megagram $[\mathrm{Mg}]=1$ metric ton). P loading from precipitation is difficult to accurately determine but is estimated to be $14.7 \mathrm{Mg} \mathrm{P} / \mathrm{yr}$ (Davis 1994). Eutrophication has resulted in a large expanse of enriched soil that has significantly influenced the vegetation composition (Davis 1994, DeBusk et al. 2001, Sklar et al. 2005). This area has also been well studied in terms of ecological structure (McCormick et al. 2002) and function (Appendix).

\section{Regime shifts}

We examined community structure and soil $\mathrm{P}$ along the surface water $\mathrm{P}$ gradient to determine if the Everglades ecosystem's response to eutrophication follows a gradual change or is marked by a sudden 
TABLE 1. Water quality and physical parameter statistics (arithmetic mean \pm SE unless otherwise stated) for the four sites that bound the study area (F4, E4, F5, and E5) in the Everglades, Florida, USA.

\begin{tabular}{|c|c|c|c|c|c|}
\hline Parameter & Units & F4 & E4 & F5 & E5 \\
\hline Geometric mean total phosphorus (GMTP) & $\mu \mathrm{g} / \mathrm{L}$ & 16 & 14 & 10 & 8 \\
\hline Total phosphorus (TP) & $\mu \mathrm{g} / \mathrm{L}$ & $18 \pm 1$ & $14 \pm 1$ & $10 \pm 1$ & $8 \pm 1$ \\
\hline Soluble reactive phosphorus (SRP) & $\mu \mathrm{g} / \mathrm{L}$ & $5 \pm 1$ & $5 \pm 1$ & $4 \pm 1$ & $4 \pm 1$ \\
\hline Total Kjeldahl nitrogen (TKN) & $\mathrm{mg} / \mathrm{L}$ & $2.18 \pm 0.05$ & $1.95 \pm 0.05$ & $2.2 \pm 0.5$ & $1.88 \pm 0.04$ \\
\hline Ammonium $\left(\mathrm{NH}_{4}\right)$ & $\mu \mathrm{g} / \mathrm{L}$ & $27 \pm 1$ & $26 \pm 2$ & $34 \pm 2$ & $28 \pm 1$ \\
\hline Nitrate-nitrite $\left(\mathrm{NO}_{\mathrm{x}}\right)$ & $\mu \mathrm{g} / \mathrm{L}$ & $10 \pm 1$ & $10 \pm 1$ & $13 \pm 1$ & $8 \pm 1$ \\
\hline Dissolved organic carbon (DOC) & $\mathrm{mg} / \mathrm{L}$ & $36.7 \pm 0.7$ & $34.1 \pm 0.7$ & $36.9 \pm 0.7$ & $33.0 \pm 0.7$ \\
\hline Dissolved silica $\left(\mathrm{SiO}_{2}\right)$ & $\mathrm{mg} / \mathrm{L}$ & $17.4 \pm 0.5$ & $15.8 \pm 0.5$ & $17.5 \pm 0.5$ & $15.9 \pm 0.5$ \\
\hline $\mathrm{pH}$ & & $7.35 \pm 0.02$ & $7.28 \pm 0.02$ & $7.49 \pm 0.02$ & $7.42 \pm 0.02$ \\
\hline Dissolved oxygen (DO) & $\mathrm{mg} / \mathrm{L}$ & $2.25 \pm 0.14$ & $2.02 \pm 0.14$ & $4.04 \pm 0.17$ & $3.72 \pm 0.14$ \\
\hline Specific conductivity & $\mathrm{mg} / \mathrm{L}$ & $958 \pm 22$ & $858 \pm 19$ & $956 \pm 24$ & $824 \pm 18$ \\
\hline Alkalinity & $\mathrm{mg} / \mathrm{L}$ & $242.5 \pm 4.8$ & $225.3 \pm 5.0$ & $236.1 \pm 4.8$ & $216.1 \pm 4.2$ \\
\hline Total dissolved chloride $(\mathrm{Cl})$ & $\mathrm{mg} / \mathrm{L}$ & $137.2 \pm 3.4$ & $121.5 \pm 2.8$ & $143.9 \pm 3.8$ & $115.6 \pm 2.8$ \\
\hline Total dissolved calcium ( $\mathrm{Ca}$ ) & $\mathrm{mg} / \mathrm{L}$ & $75.5 \pm 1.6$ & $69.3 \pm 1.4$ & $71.3 \pm 1.6$ & $67.0 \pm 1.3$ \\
\hline Total dissolved copper $(\mathrm{Cu})$ & $\mathrm{mg} / \mathrm{L}$ & $1.1 \pm 0.2$ & $0.9 \pm 0.1$ & $1.2 \pm 0.2$ & $0.9 \pm 0.1$ \\
\hline Total dissolved magnesium $(\mathrm{Mg})$ & $\mathrm{mg} / \mathrm{L}$ & $25.3 \pm 0.7$ & $22.5 \pm 0.6$ & $25.5 \pm 0.6$ & $21.8 \pm 0.5$ \\
\hline Total dissolved potassium (K) & $\mathrm{mg} / \mathrm{L}$ & $7.2 \pm 0.2$ & $6.6 \pm 0.1$ & $7.0 \pm 0.2$ & $6.3 \pm 0.1$ \\
\hline Total dissolved sodium $(\mathrm{Na})$ & $\mathrm{mg} / \mathrm{L}$ & $96.8 \pm 2.6$ & $84.5 \pm 1.8$ & $101 \pm 2.6$ & $80.4 \pm 1.8$ \\
\hline Total dissolved zinc ( $\mathrm{Zn})$ & $\mathrm{mg} / \mathrm{L}$ & $2.8 \pm 0.4$ & $3.3 \pm 0.5$ & $3.6 \pm 0.4$ & $2.7 \pm 0.4$ \\
\hline Dissolved sulfate $\left(\mathrm{SO}_{4}\right)$ & $\mathrm{mg} / \mathrm{L}$ & $50.0 \pm 2.0$ & $44.1 \pm 1.8$ & $47.2 \pm 2.0$ & $42.0 \pm 1.8$ \\
\hline Temperature & ${ }^{\circ} \mathrm{C}$ & $23.9 \pm 0.4$ & $23.8 \pm 0.4$ & $24.3 \pm 0.4$ & $24.5 \pm 0.4$ \\
\hline Depth & $\mathrm{m}$ & $0.39 \pm 0.2$ & $0.41 \pm 0.03$ & $0.44 \pm 0.02$ & $0.48 \pm 0.03$ \\
\hline
\end{tabular}

Note: Means were determined using monthly data collected between 1994 and 2003.

shift or threshold effect. We utilized 13 long-term monitoring sites that emanate from the S10 structures and extend more than $10 \mathrm{~km}$ into the marsh interior (Fig. 1) for the regime shift analysis. Surface water and soil TP were considered the slower or independent variables that could potentially lead to a shift and that could be used to define the spatial position of the threshold. The site specific five-year GMTP was determined from water samples collected monthly from each site. We used the five-year GMTP because the critical $10 \mu \mathrm{g} \mathrm{P} / \mathrm{L}$ TP concentration deemed protective of the Everglades is based on a five-year geometric mean. In February 2004, triplicate soil cores were collected, using a thin-walled stainless steel corer, from each of the dominant vegetation communities (Typha, Cladium, or slough) present at each site. Cores $(10 \mathrm{~cm}$ in diameter $)$ were separated into three fractions, floc (pourable fraction consisting of unconsolidated soil, plant detritus, and algae), soil $0-10 \mathrm{~cm}$ deep, and soil $10-30 \mathrm{~cm}$ deep (see Bruland et al. 2007). Each fraction was analyzed for TP by DB-Environmental Laboratories (in Rockledge, Florida, USA) using standard methods.

We utilized the percent cover of the major vegetation communities as the fast or dependent response variables (i.e., the variables that are radically altered during a shift) to determine if regimes were altered as a function of the independent slow variable $\mathrm{P}$ concentration (i.e., the variable that leads to the shift and defines the threshold) (Walker and Meyers 2004). Percent cover within a $1 \mathrm{~km}$ radius (area $3.14 \mathrm{~km}^{2}$ ) of each site was estimated using the 2003 WCA-2A vegetation map derived from 1:24000 scale color-infrared positive color transparencies (Rutchey et al., in press). The map consisted of the dominant vegetation type in $50 \times 50$ m grid cells. Approximately 1380 grid cells per site were used to derive the cover estimates. Regime shifts were detected by fitting linear and nonlinear models to phosphorus parameters and vegetation percent cover.

\section{Slough regime shift boundary}

We examined in greater detail the response of sloughs to eutrophication by examining sloughs in a $12.3-\mathrm{km}^{2}$ area delineated by four long-term monitoring sites $\mathrm{F} 4$, E4, F5, and E5 (Fig. 1) with long-term geometric mean TP concentrations that straddle the critical $10 \mu \mathrm{g} \mathrm{P} / \mathrm{L}$ (Table 1). Sloughs were not present north of F4 and E4. We conducted two synoptic surveys in November 2002 and October 2003 to characterize water quality, soil properties, and vegetation structure. Forty-five randomly selected sloughs were sampled in 2002. In 2003, the same 45 sloughs were resampled and eight additional sloughs, including the four long-term monitoring sites, were sampled. Water quality samples were collected and analyzed for a suite of parameters; however, here we focus primarily on TP. All surface water samples were analyzed by the South Florida Water Management District's (SFWMD) Chemistry Laboratory (West Palm Beach, Florida, USA) using standard methods. To establish the GMTP concentration in sloughs, we collected surface water samples from 33 of the 49 sloughs monthly between March and October 2003, via helicopter.

To characterize soils, a single core $(5 \mathrm{~cm}$ in diameter) was collected from each slough in 2002 and 2003, using a thin-walled butyrate tube. Three replicate cores were collected from each of the four long-term monitoring sites in 2003. In the laboratory, cores were separated into three fractions, benthic (distinct cohesive algal 


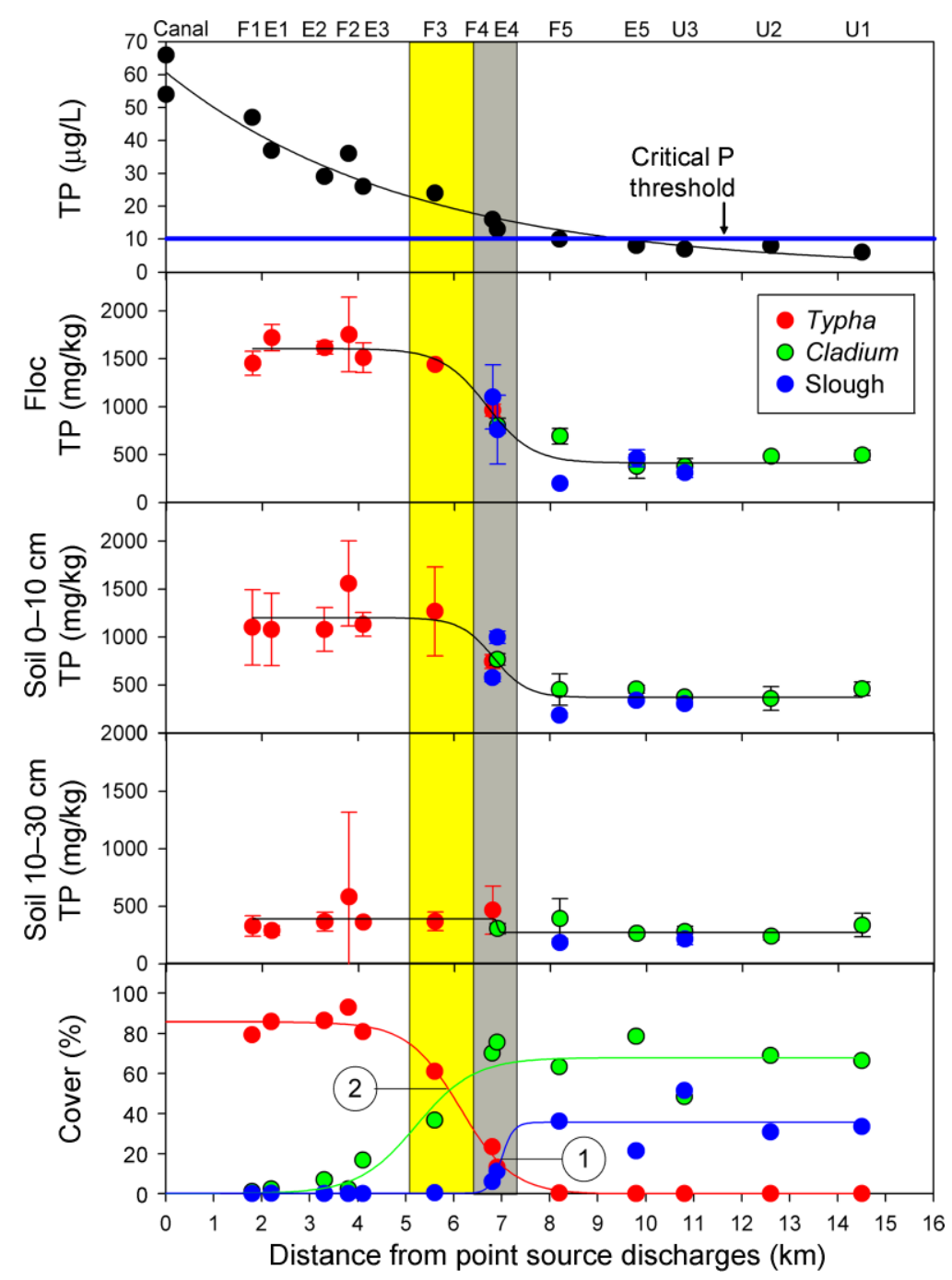

FIG. 3. The distribution of total phosphorus (TP) in surface water (top panel) and from the three core fractions (floc [pourable, consisting of unconsolidated soil, plant detritus, and algae], soil $0-10 \mathrm{~cm}$ deep, and soil $10-30 \mathrm{~cm}$ deep), and vegetation cover in WCA-2A, with distance from the S10 point source discharges on the L-39 canal (denoted by F0 and E0 in Fig. 1). Values are means; error bars show \pm SD. Black circles in the top panel represent surface water TP concentrations collected from the monitoring stations. The heavy blue line in the top panel indicates the 5-year geometric mean total P (GMTP) concentration of 10 $\mu \mathrm{g} / \mathrm{L}$ deemed the critical threshold that is protective of the Everglades (State of Florida Class III water quality criterion, Florida Statute Chapter 62-302.540). Percent cover of Typha, Cladium, and slough was estimated within a 1-km radius of each transect site. Points 1 and 2 (in large open circles) indicate where Typha begins to replace slough and Cladium communities, respectively. The yellow and gray bars further highlight the $\mathrm{P}$ conditions associated with the vegetation shifts.

layer), floc (pourable fraction consisting of unconsolidated soil, plant detritus, and algae), and soil $(0-10 \mathrm{~cm})$. In 2002, fractions were analyzed for ash content, total nitrogen (TN), and TP. The analysis was expanded in 2003 to include total calcium (Ca), total carbon (TC), and total organic carbon (TOC). For the purposes of this study, we refer to surficial soils consisting of benthic algae and/or floc fractions as the benthic algal floc layer (BAFL). Not all cores had each fraction. BAFL and soils were analyzed by DB-Environmental Laboratories using standard methods.

Relationships between $\mathrm{P}$ and slough vegetation were assessed using the GIS vegetation classification scheme of Rutchey et al. (2006). Sloughs were classified into four community types based on the dominant vegetation cover (Fig. 2): (1) periphyton (P; class identifier), openwater freshwater marsh dominated by floating and/or submergent periphyton species; (2) open marsh (MFO), open-water-dominated freshwater marsh with a mix of sparse graminoids, herbaceous, and/or emergent vegetation, such as Eleocharis spp. (spikerush), low-stature Cladium jamaicense, Typha sp., and Nymphaea sp., among others; (3) Nymphaea (MFFy), Nymphaea odorata-dominated marsh; and (4) "other," small open-water areas, typically with low-stature Cladium, that did not fall within the GIS classification scheme. Vegetation 

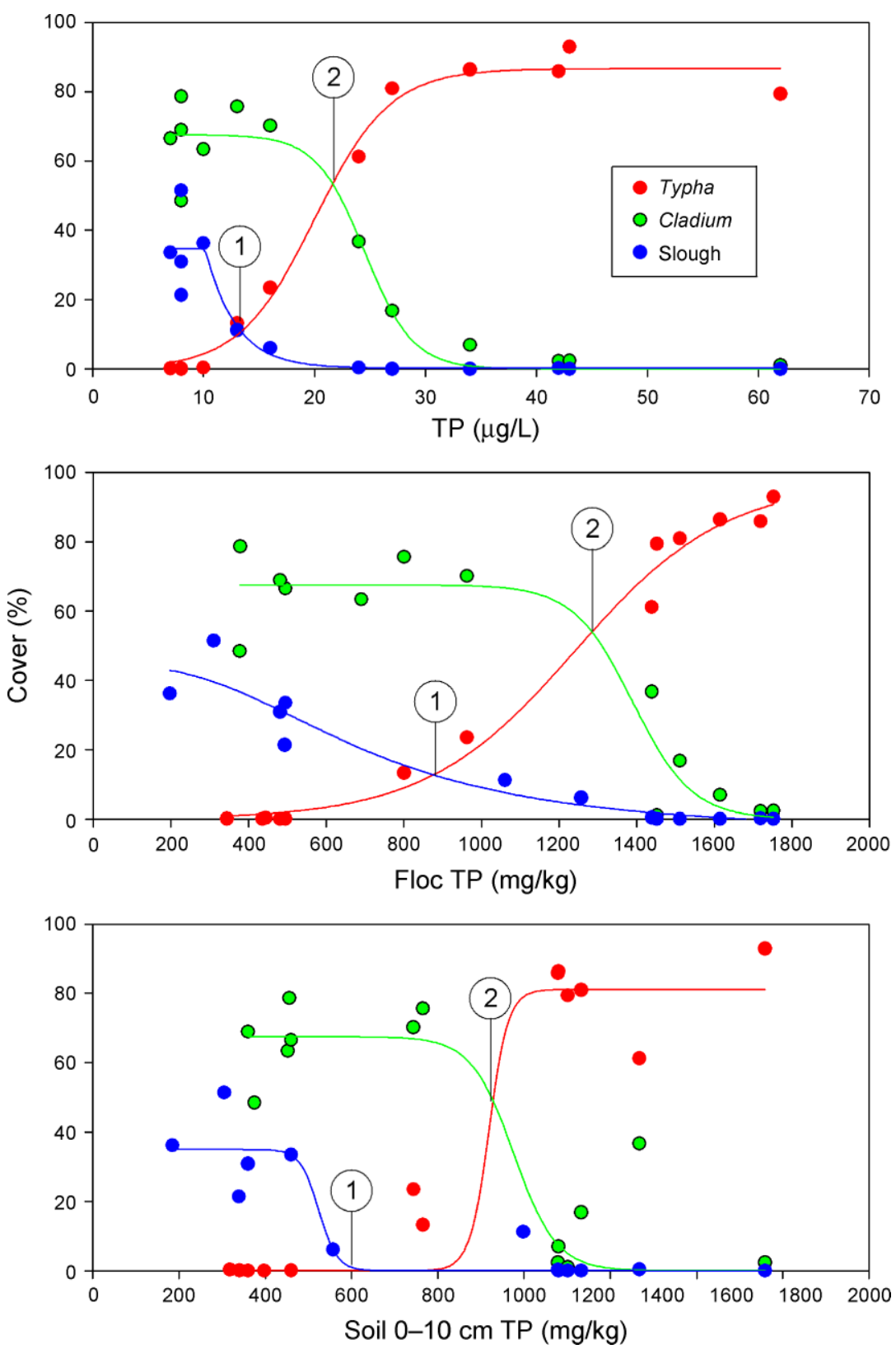

FIG. 4. Nonlinear relationship between the controlling variable (TP) and the ecosystem state variables (vegetation cover of different types). Points 1 and 2 (in large open circles) denote where critical $\mathrm{P}$ thresholds were surpassed and resulted in shifts from the slough and Cladium low-nutrient stability regimes to the high-nutrient Typha stability regime. Note that the percent cover of Typha increases as slough cover decreases without a subsequent shift in Cladium cover (point 1). This suggests that there are two low-nutrient stability regimes (slough and Cladium) and that they respond to eutrophication differently.

classification relied on stereoscopic analysis of 1:24000 scale color-infrared positive transparencies $(23 \times 23 \mathrm{~cm}$ format) flown in January 2003. Polygons were delineated with PRO600 (version 8.0, Leica Geosystems, Norcross, Georgia, USA) and Microstation (version 8.05, Bentley Systems, Exton, Pennsylvania, USA) software as part of the Leica-Geosystems SD2000 analytical stereoplotter (Leica Geosystems, Norcross, Georgia, USA). Delineation of the polygons was performed utilizing superimposition technology, which allowed for polygons to be developed overtop of the threedimensional stereo imagery. All Microstation files were then translated into a final ArcINFO (version 9.1 Environmental Systems Research Institute, Redlands, California, USA) coverage and hard-copy maps were produced.

To determine if macrophytes were influenced by lowlevel $\mathrm{P}$ enrichment, we examined the TP and $\mathrm{TN}$ in 


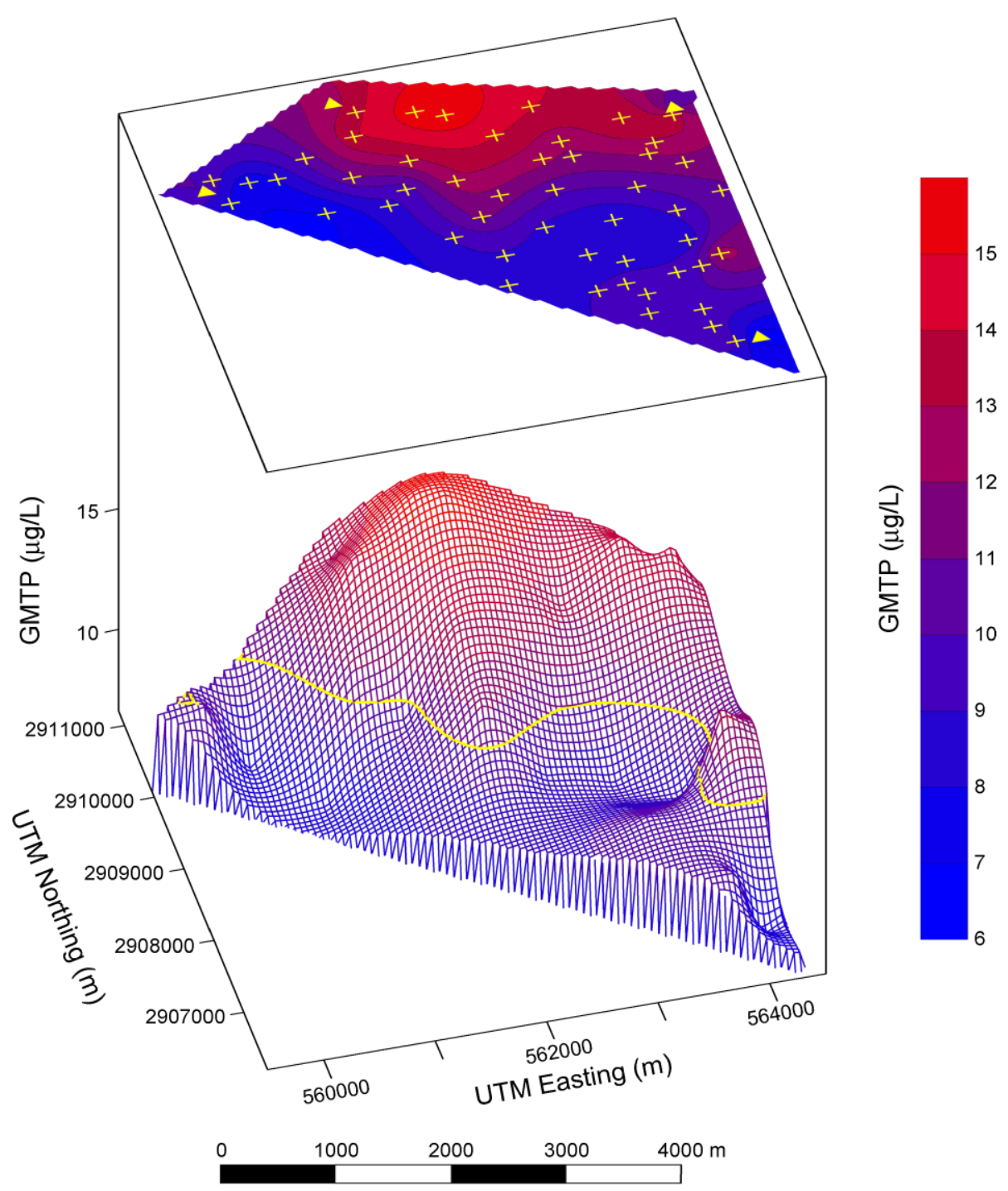

FIG. 5. Two- and three-dimensional surface contour plots for 2003 geometric mean total phosphorus (GMTP). Slough survey locations (yellow crosses) and the long-term monitoring sites F4, E4, F5, and E5 (yellow triangles) are shown in the upper 2-D plot. The contour for $10 \mu \mathrm{g} \mathrm{TP} / \mathrm{L}$ is highlighted in yellow. This line reflects the TP concentration deemed protective of the Everglades ecosystem.

leaves of Nymphaea because this species was a common biological feature of all the sloughs in the study area. During the synoptic surveys, three leaves were collected from each slough and stored on ice until analyzed by DB-Environmental Laboratories using standard methods.

\section{Statistics}

Common statistical procedures (e.g., ANOVA and correlation analysis) were completed using SAS-JMP, version 5.1 (SAS Institute, Cary, North Carolina, USA). Critical thresholds were determined using parametric statistical change point analysis (Chen and Gupta 2000). We assumed that the ecological responses within the boundary were nonlinear (threshold based), but exam- ined all relationships using simple linear regression to assess whether the threshold model improved upon the fit of the regression model. We calculated the concentration of the independent controlling variable, the ecological driver P (GMTP, BAFL TP, and soil TP), at which significant differences occurred for the mean concentration of the dependent ecosystem state variables (BAFL and soil TOC, Ca, ash, and TN; Nymphaea leaf TP and TN). Both the case of a single threshold and two possible thresholds for each dependent variable were examined using an optimization approach to estimate the $\mathrm{P}$ threshold, accompanied by bootstrapping to test for significance of the threshold (Manly and Francis 2002). The threshold analysis was coded in SAS, version 8 (SAS Institute, Cary, North Carolina, USA). 
We used kriging to visualize the spatial pattern of surface water, BAFL, and soil variables (Cressie 1991). Kriging was done with no error nugget effect, which honors data points exactly when the point coincides with the grid node being interpolated. Surfer software (version 8.0, Golden Software, Golden, Colorado, USA) was used to generate two- and three-dimensional surface contour plots for BAFL and soil TP, Ca, and TOC, and GMTP.

\section{RESULTS \\ Regime shifts}

Along a surface water TP gradient, abrupt changes in dominant marsh vegetation and soil $\mathrm{P}$ content were observed (Fig. 3). Vegetation percent cover for the lownutrient marsh interior consisted of $63 \%$ Cladium and $35 \%$ slough. The high-nutrient marsh consisted of $85 \%$ Typha. Cladium and sloughs responded differently to eutrophication at the landscape scale. Slough areal extent declined rapidly when surface water TP exceeded $10 \mu \mathrm{g} \mathrm{P} / \mathrm{L}$ and floc and soil $(0-10 \mathrm{~cm})$ TP exceeded 500 $\mathrm{mg} \mathrm{P} / \mathrm{kg}$ (Fig. 3; yellow box). These declines were best characterized by significant $(P<0.001)$ nonlinear regressions (surface water TP $r^{2}=0.91$; floc TP $r^{2}=$ 0.92 ; soil $[0-10 \mathrm{~cm}] r^{2}=0.95$; Fig. 4). Concomitant increases in the areal extent of Typha $(0 \%$ to $>15 \%)$ followed the decline in sloughs (Fig. 4; point 1). In contrast, Cladium remained a conspicuous component of the landscape (i.e., $>60 \%$ ) until $\mathrm{P}$ exceeded $15 \mu \mathrm{g} / \mathrm{L}$ in the surface water, and $1100 \mathrm{mg} / \mathrm{kg}$ in the floc and soil [0$10 \mathrm{~cm}$ ] (Fig. 3; gray box). Cladium declines were also best described by nonlinear regressions (surface water $r^{2}$ $=0.95$; floc $r^{2}=0.95$; soil $[0-10 \mathrm{~cm}] r^{2}=0.87$; Fig. 4). Typha increased following the decline in Cladium (Fig. 4; point 2). Nonlinear dynamics also best reflected the increase in Typha, with the shift ending when $\mathrm{P}$ exceeded $40 \mu \mathrm{g} / \mathrm{L}$ in the surface water $\left(r^{2}=0.99\right), 1700 \mathrm{mg} / \mathrm{kg}$ in the floc $\left(r^{2}=0.99\right)$, and $1200 \mathrm{mg} / \mathrm{kg}$ in the soil $0-10 \mathrm{~cm}$ fraction $\left(r^{2}=0.94\right)$; see Fig. 3 . The shift from slough to Typha without an intermediate Cladium state (Fig. 4; points 1 and 2) indicates that the processes that lead to changes in the state variables are fundamentally different between the two communities that define the low-nutrient stability regime.

\section{Slough-Typha regime shift boundary}

We examined in greater detail the transition of slough to Typha (Fig. 3; yellow box). The monitoring sites E4 and F4 delineated the northernmost extent of sloughs, whereas E5 and F5 delineated unimpacted low-nutrient sloughs. Within this boundary, surface water GMTP for the 29 sloughs ranged between 7 and $16 \mu \mathrm{g} / \mathrm{L}$. Spatially, GMTP decreased along a north-south gradient (Fig. 5), corresponding to the approximate elevation and flow gradient downstream of the point source S10 inflow structures.

Soil spatial patterns.-BAFL properties were all highly and significantly correlated, and soil properties
TABLE 2. Pearson correlation coefficients among nutrient concentrations and organic content for benthic algal floc layers (BAFL) and soils $(0-10 \mathrm{~cm})$ collected in the 2003 slough survey from WCA-2A, Everglades, Florida, USA.

\begin{tabular}{lrrrrr}
\hline \hline $\begin{array}{c}\text { Core content, } \\
\text { by fraction }\end{array}$ & Ash & Ca & TOC & $\log$ TN & $\log$ TP \\
\hline BAFL & & & & & \\
Ash & 1.000 & & & & \\
Ca & 0.992 & 1.000 & & & \\
TOC & -0.987 & -0.986 & 1.000 & & \\
log TN & -0.945 & -0.934 & 0.931 & 1.000 & \\
log TP & -0.797 & -0.781 & 0.780 & 0.891 & 1.000 \\
Soil (0-10 cm) & & & & & \\
Ash & 1.000 & & & & \\
Ca & 0.820 & 1.000 & & & \\
TOC & -0.809 & -0.985 & 1.000 & & \\
$\log$ TN & -0.769 & -0.923 & 0.908 & 1.000 & \\
$\log$ TP & -0.332 & -0.358 & 0.342 & 0.372 & 1.000 \\
\hline
\end{tabular}

Notes: All correlations were significant $(P<0.015) ; n=53$ cores. Cores $(10 \mathrm{~cm}$ diameter $)$ were separated into three fractions: floc (the pourable fraction consisting of unconsolidated soil, plant detritus, and algae), soil 0-10 cm deep, and soil 10-30 $\mathrm{cm}$ deep (not shown here).

were, with the exception of TP, highly correlated (Table 2). BAFL $\mathrm{Ca}$ and ash were positively correlated and both were negatively correlated with TOC, $\log \mathrm{TN}$, and $\log \mathrm{TP}$, whereas $\log \mathrm{TP}$ and $\log \mathrm{TN}$ were positively correlated with TOC. Soil log TP was poorly correlated with ash, Ca, TOC, and TN $(r<0.37)$. BAFL parameters were correlated between 2002 and 2003 $\left(r_{\mathrm{TP}}=0.88, r_{\mathrm{TN}}=0.77, r_{\mathrm{ash}}=0.75\right)$. In contrast, soil parameters were poorly correlated between years $\left(r_{\mathrm{TP}}=\right.$ $\left.0.59, r_{\mathrm{TN}}=0.42, r_{\mathrm{ash}}=0.38\right)$. Moreover, within a slough, there was no consistent pattern in BAFL or soil between years (i.e., 2003 was neither consistently higher nor lower than 2002), suggesting that the variation between years reflects within-slough variability rather than temporal trends.

BAFL nutrient concentrations varied along a northsouth gradient. BAFL TP in 2003 ranged between 130 and $1270 \mathrm{mg} / \mathrm{kg}$ and declined abruptly, from greater than 1000 to less than $500 \mathrm{mg} / \mathrm{kg}$ over a distance of less than $750 \mathrm{~m}$ (Fig. 6). The spatial distribution of TN was similar to that of TP. BAFL TN ranged between 10 and $43 \mathrm{~g} / \mathrm{kg}$, with the highest values occurring near sites F4 and E4 and declining toward F5 and E5. Organic BAFLs characterized the northern portion and calcitic BAFLs (marl) characterized the southwestern portion of the study area (Fig. 7A, B). TOC and Ca were inversely related and ranged from 205 to $463 \mathrm{~g} \mathrm{C} / \mathrm{kg}$ and 20 to 233 $\mathrm{g} \mathrm{Ca} / \mathrm{kg}$, respectively. BAFL ash content ranged from $7 \%$ near $\mathrm{F} 4$ to $75 \%$ at F5 and followed a trend similar to that of $\mathrm{Ca}$.

Soil nutrients were spatially distributed along a north-south gradient much like the overlying BAFL (data not shown). Ranges for soil TP (147-1130 mg/kg), TN (12-38 g/kg), TOC (144-479 g/kg), Ca (15-240 $\mathrm{g} / \mathrm{kg}$ ), and ash (8.3-88.4\%) were similar to BAFL ranges. Paired soil nutrients were weakly associated with the 


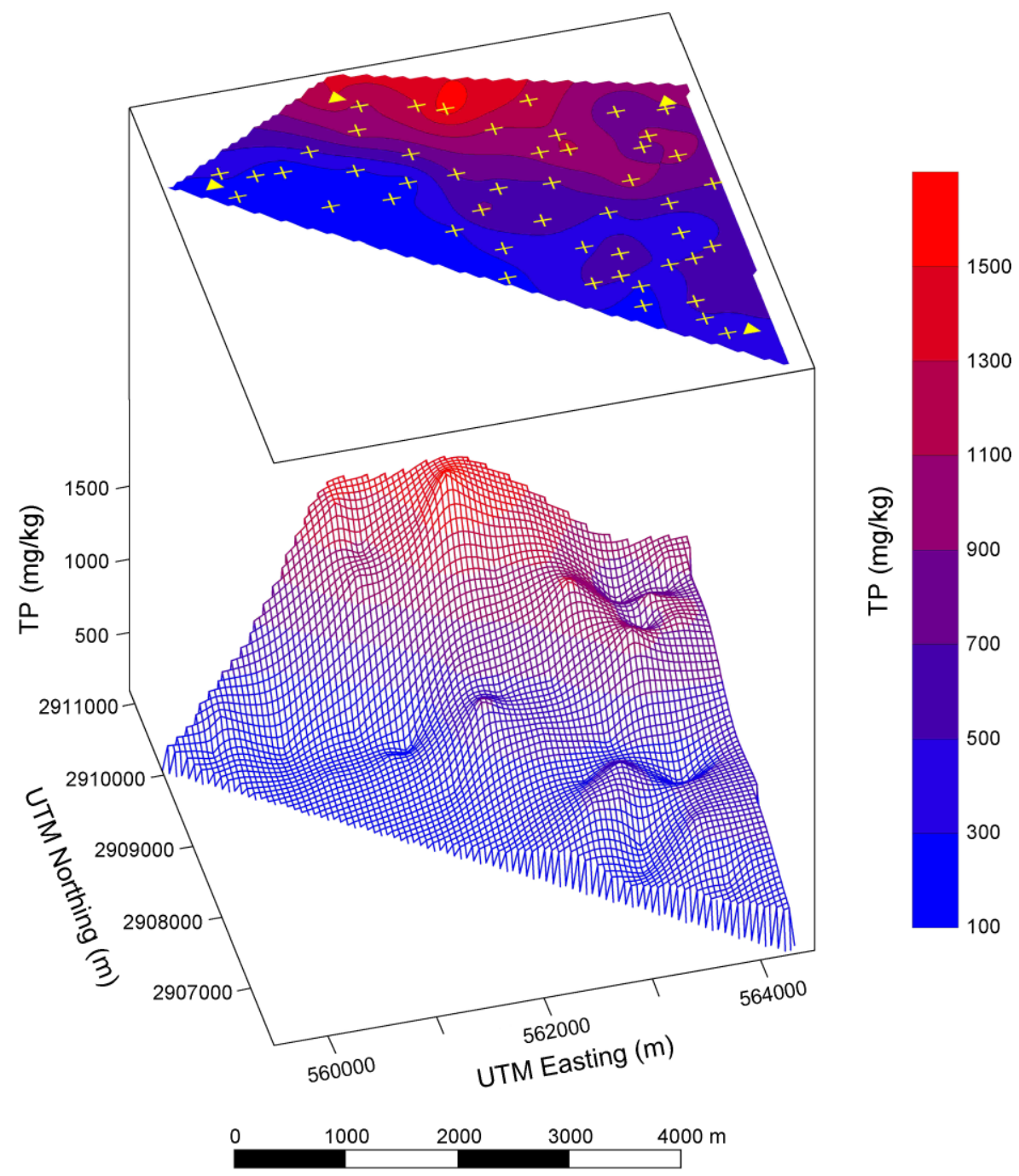

FIG. 6. Two- and three-dimensional surface contour plots of the 2003 benthic algal floc layer total phosphorus (BAFL TP). Slough survey locations and monitoring sites are shown in the upper 2-D plot, as in Fig. 5.

overlying BAFL $\left(r_{\mathrm{TP}}=0.49, r_{\mathrm{TN}}=0.68, r_{\mathrm{TOC}}=0.67, r_{\mathrm{Ca}}\right.$ $\left.=0.60, r_{\text {ash }}=0.54\right)$.

Community structure.-Based on the GIS vegetation classification, 12 sloughs were classified as periphyton, 18 as open marsh, 12 as Nymphaea, and 11 as "other" (Fig. 8). Periphyton-classified sloughs were restricted to the southern portion, whereas Nymphaea sloughs predominantly occurred along the northern portion of the study site. Periphyton sloughs were composed of dense calcareous metaphyton, Utricularia purpurea, Chara sp., Eleocharis cellulosa, and Nymphaea odorata (Fig. 2B). Large leaves of Nymphaea odorata covered the surface of Nymphaea sloughs (Fig. 2D). Utricularia gibba, Utricularia radiata, and Typha domingensis were also present. Open-marsh sloughs occurred throughout the study area, but typically bounded the periphyton sloughs to the south and the Nymphaea sloughs to the north. The vegetation composition was similar to periphyton sloughs except that the calcareous metaphyton was lacking and Utricularia foliosa was more prevalent. Dense thickets of Eleocharis cellulosa were also observed (Fig. 2C). Sloughs classified as "other" were small, intermittent openings in stands of dense Cladium (Fig. 2A) and were significantly shallower than the other classes (Table 3). This suggests that "other" sloughs may actually be part of the Cladium ridge and not an actual slough. Non-calcareous metaphyton, Utricularia purpurea, and Utricularia foliosa were prevalent, as was a greater abundance of short-stature Cladium. These sites, in general, were found in the southeastern portion of the boundary. Vegetation surrounding the sloughs was primarily Cladium. Typha cover was $<10 \%$ around 47 of the sloughs. Five sloughs located along the northern edge of the study site had cattail cover of $10-49 \%$ and one had cover of $50-89 \%$. 


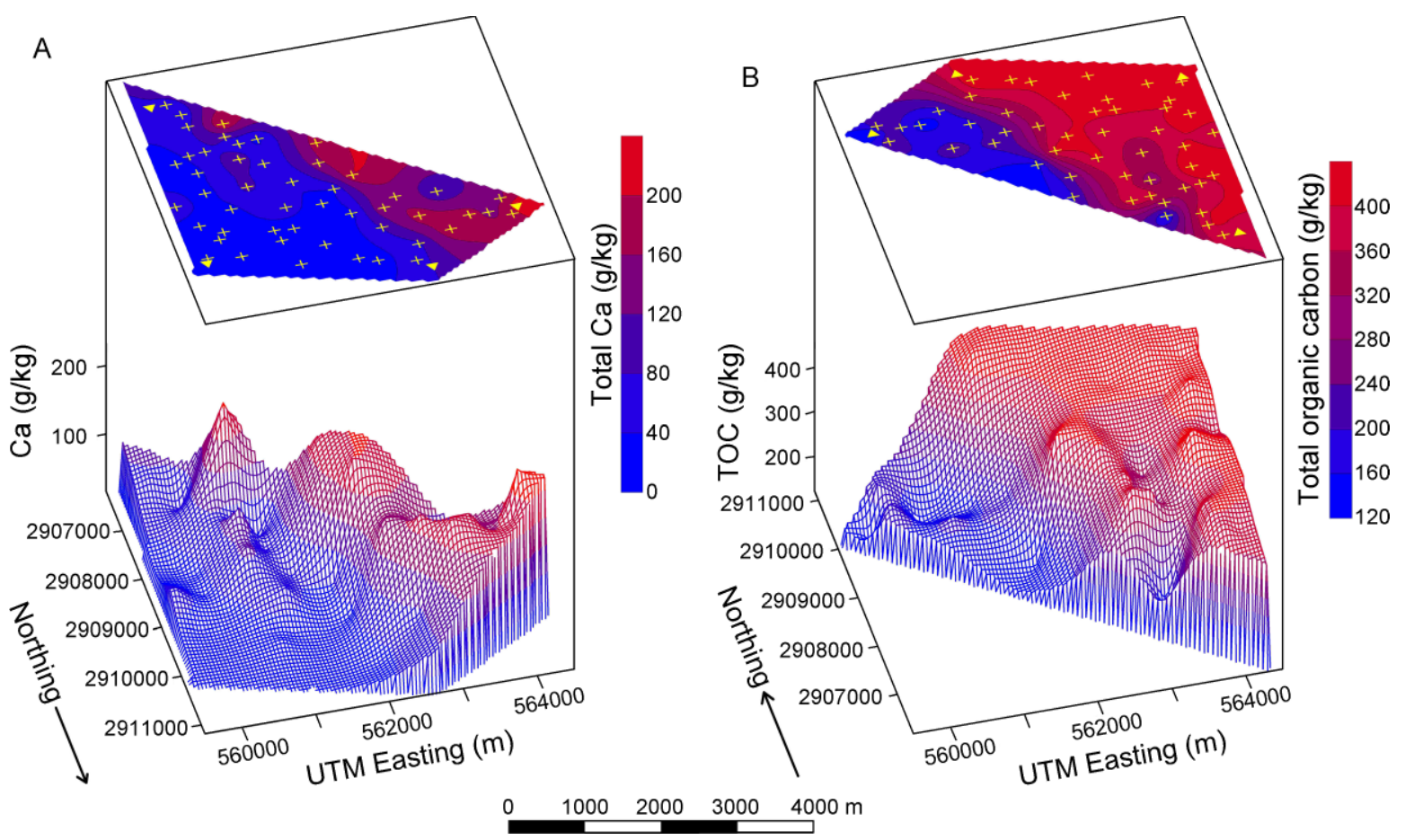

FIG. 7. Two- and three-dimensional surface contour plots of (A) BAFL Ca and (B) BAFL TOC. Note that the Ca plot is oriented from north to south to illustrate the lower concentrations in the northern section of the study area. Slough survey locations and monitoring sites are shown in the upper 2-D plots, as in Fig. 5.

GMTP, BAFL, and soil variables differed significantly among the four vegetation-classified sloughs (Table 3). The GMTP for the Nymphaea class $(13 \pm 2 \mu \mathrm{g} / \mathrm{L}$; values reported as means $\pm \mathrm{SD}$ throughout) was significantly greater than the open-marsh $(10 \pm 2$ $\mu \mathrm{g} / \mathrm{L})$, "other" $(9 \pm 2 \mu \mathrm{g} / \mathrm{L})$, and periphyton $(9 \pm 1$ $\mu \mathrm{g} / \mathrm{L})$ classes. BAFL TP concentrations were significantly greater for Nymphaea and open-marsh sloughs than for periphyton and "other." Compared to "other" and open-marsh sloughs, BAFL TN was significantly lower and higher for periphyton and Nymphaea sloughs, respectively. BAFL ash and $\mathrm{Ca}$ values for periphyton sloughs were more than double those of the other three classes, whereas TOC values were significantly lower. Soil $(0-10 \mathrm{~cm})$ TP for Nymphaea sloughs was nearly twofold greater than for the other slough classes. Soil TN was significantly lower and higher for periphyton and Nymphaea sloughs than for "other" and open marsh. Soil ash, $\mathrm{Ca}$, and TOC in periphyton sloughs were significantly different than in the other three slough classes.

Nymphaea leaf nutrient TP followed a similar, albeit more variable, pattern to that observed for other BAFL and surface water variables. Leaf TP ranged from 740 $\mathrm{mg} / \mathrm{kg}$ in the southern portion of the study area to a high of $1580 \mathrm{mg} / \mathrm{kg}$ in the northern half. Leaf TN values ranged from 18 to $29 \mathrm{~g} / \mathrm{kg}$ and had a spatial pattern similar to that of leaf TP. Leaf TP was positively related to BAFL TP $(r=0.69)$ and soil TP $(r=0.47)$. Leaf TP was significantly greater for Nymphaea sloughs than for the other three vegetation classes; however, leaf TN only differed between the "other" and Nymphaea class (Table 3). Similarly, mean leaf N:P (molar) for the Nymphaea class (N:P ratio $45 \pm 7$, mean $\pm \mathrm{SD}$ ) was significantly lower than for the periphyton $(55 \pm 7)$ and "other" class $(53 \pm 4)$ (ANOVA $\left.F_{3,49}=6.42, P<0.001\right)$, but not than for the open-marsh class $(51 \pm 6)$.

\section{Change point analysis}

GMTP change points were identified for all BAFL variables (Table 4). Model coefficients generally indicated poor fits $\left(r^{2}\right.$ range $\left.0.22-0.54\right)$ caused by weaker separation into groups due to higher variance or slight sloping behavior within groups. The change point for BAFL TP occurred at $11 \mu \mathrm{g}$ GMTP/L. BAFL TP averaged $442 \mathrm{mg} / \mathrm{kg}$ below and $1004 \mathrm{mg} / \mathrm{kg}$ above the change point (Fig. 9A). Change points for BAFL Ca, ash content, and TN also occurred at a GMTP $\leq 11$ $\mu \mathrm{g} / \mathrm{L}$. Change point models showed slight improvements over linear regression models, with the exception of TN $\left(r^{2}=0.43\right)$. There was a consistent pattern between the vegetation classification and the GMTP change point (Fig. 9A). The periphyton and "other" classes dominated sloughs below the change point. Nymphaea dominated above the change point and open marsh straddled the value. Although few soil parameters were significantly related to GMTP at $\alpha=0.05$, weaker relationships ( $P=$ 


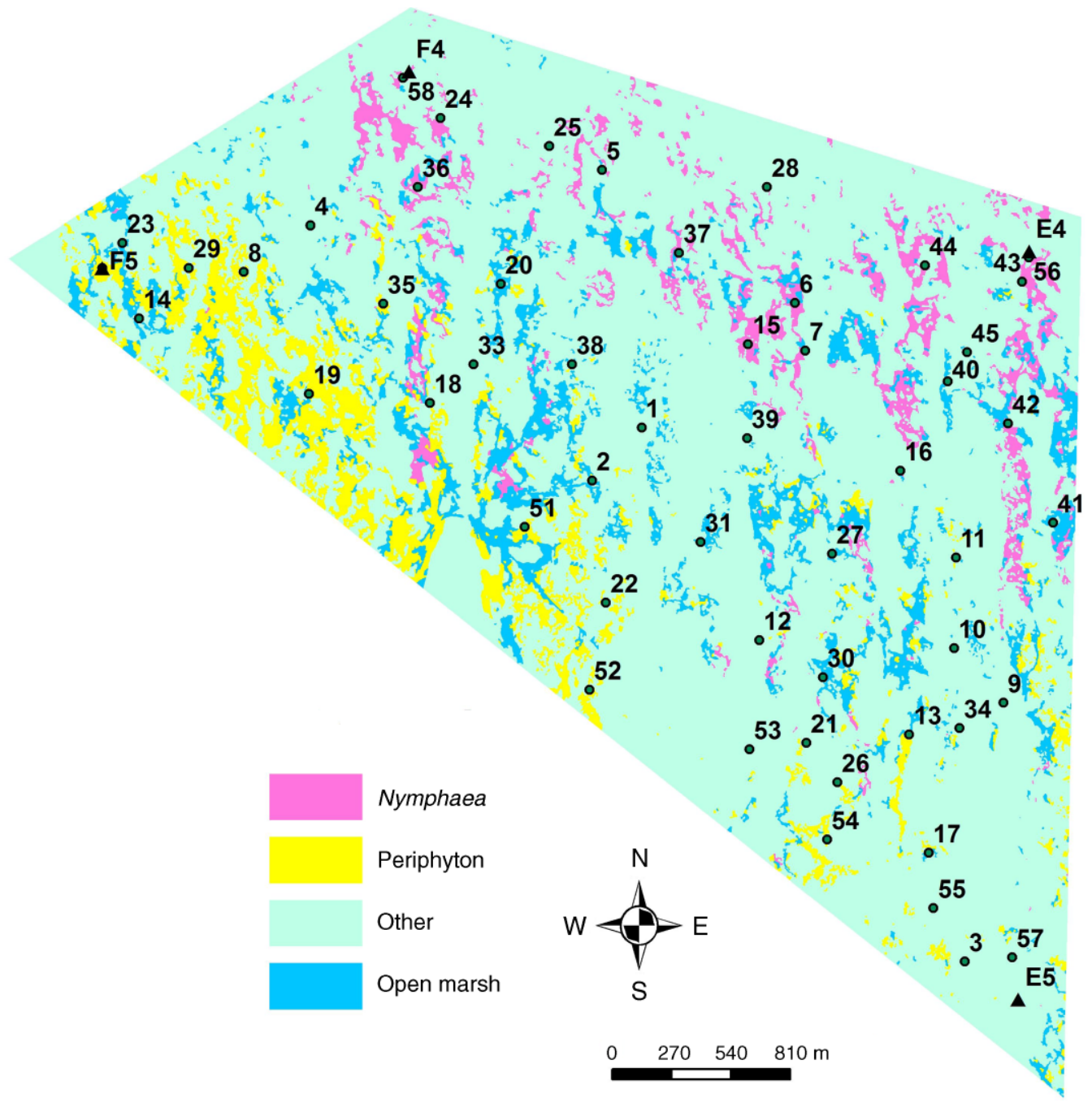

FIG. 8. Location of the randomly selected sloughs sampled in 2002 and 2003 (numbered solid circles). A four-class vegetation classification is overlain on the study area. Sloughs are depicted by the periphyton, open marsh, and Nymphaea classes. Broad expanses of "other" are representative of (Cladium) ridges. Sites located in class "other" tended to be sloughs small in areal extent and surrounded by Cladium.

0.06-0.08) suggested the potential for change points with similar GMTP concentrations observed for BAFLs.

No significant change points were determined for soil TP; however, multiple change points were associated with BAFL TP (Table 4). Change points occurred at 226 and $712 \mathrm{mg} \mathrm{TP} / \mathrm{kg}$ for $\mathrm{Ca}$, TOC, and ash. The first change point was associated with a shift from marl to organic BAFLs. The second change point was associated with an increase in the $\mathrm{P}$ content of organic BAFLs (Fig. 9B). Change points also coincided with the vegetation classification (Fig. 9B). For example, below $226 \mathrm{mg} \mathrm{TP} / \mathrm{kg}$, TOC values were $<191 \mathrm{~g} / \mathrm{kg}$ and the sloughs were classified as periphyton. Above $712 \mathrm{mg}$ $\mathrm{TP} / \mathrm{kg}$, TOC values were $>410 \mathrm{~g} / \mathrm{kg}$ and the sloughs were classed as Nymphaea. Sloughs with $226-712 \mathrm{mg}$ $\mathrm{TP} / \mathrm{kg}$ and 191-410 g TOC/kg were classified as open marsh or "other."
A single change point for GMTP $(\leq 10 \mu \mathrm{g} / \mathrm{L})$ was detected for Nymphaea leaf TP (Table 4). Single BAFL TP change points were also detected for Nymphaea leaf TP $(<700 \mathrm{mg} / \mathrm{kg})$ and TN $(<672 \mathrm{mg} / \mathrm{kg})$ (Table 4). The mean leaf nutrient content above the change points ranged from 1180 to $1263 \mathrm{mg} \mathrm{TP} / \mathrm{kg}$ and $>26 \mathrm{~g} \mathrm{TN} / \mathrm{kg}$. Leaf N:P (molar) differed significantly between the BAFL TP change points (below $700 \mathrm{mg} \mathrm{TP} / \mathrm{kg}=54 \pm 5$; above $700 \mathrm{mg} \mathrm{TP} / \mathrm{kg}=46 \pm 6$; $t$ test, $P<0.001)$.

\section{Discussion}

These results suggest that the low-nutrient stability regime in the Everglades marsh is defined by both Cladium and sloughs. The nonlinear dynamics that describe the replacement of these community types with the high-nutrient Typha stability regime are indicative of a regime shift. More importantly, eutrophication of the 
TABLE 3. Grouped means ( \pm SD) for GMTP, water depth, BAFL, soil $(0-10 \mathrm{~cm})$, and Nymphaea leaf nutrient content for sloughs classified according to vegetation characteristics.

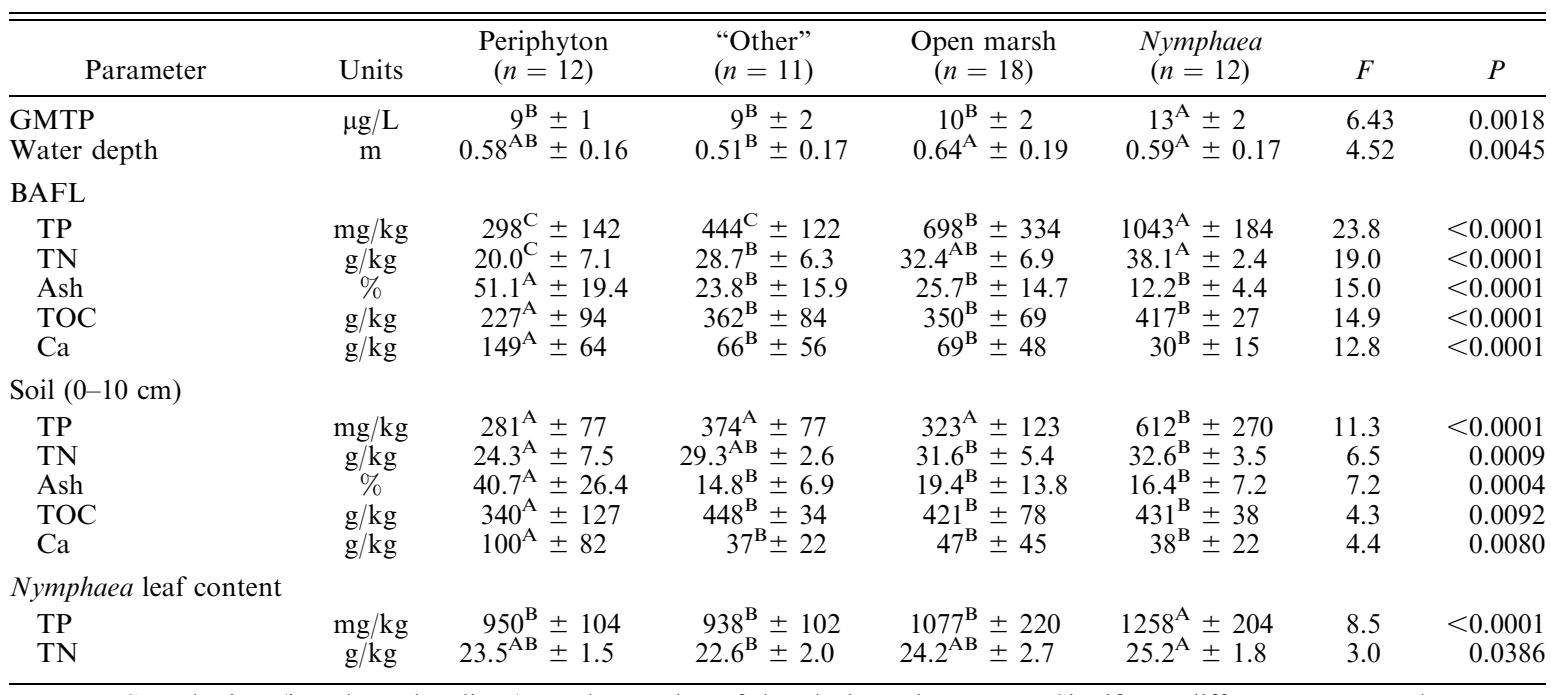

Notes: Sample sizes (in column headings) are the number of sloughs in each category. Significant differences among classes were determined using one-way ANOVA. Values with the same uppercase superscript letter are not significantly different (Tukey's test, $P>0.05)$. Water depths were measured four times between November 2002 and 2003 . For all $F$ values, $\mathrm{df}=3,49$ except for GMTP $(\mathrm{df}=3,29)$. GMTP is the geometric mean total phosphorus.

Everglades low-nutrient stability domain does not follow a simplistic succession from slough to Cladium to Typha. Instead, sloughs and Cladium respond independently and differently to $\mathrm{P}$ enrichment, as evidenced by different critical $\mathrm{P}$ thresholds (Figs. 3 and 4).

Threshold effects cause sudden changes in ecosystem feedbacks, resulting in regime shifts (Scheffer and Carpenter 2003, Folke et al. 2004, Walker and Meyers 2004). A threshold effect was used to explain the nutrient-induced shift from Cladium to Typha in the Everglades (Gunderson 2001). Soil P defined these alternate stable states, with disturbances (e.g., fires, drought, or freezes) probably triggering the switch. Our observation of the slough-Typha boundary implicates eutrophication as the primary driver responsible for the expansion of Typha into sloughs through erosion of resilience. Our results suggest that once a critical threshold in water column GMTP $(\sim 10-11 \mu \mathrm{g} / \mathrm{L})$ was exceeded, the resilience of the slough ecosystem was surpassed and rapidly declined from an unenriched periphyton-open marsh slough community to a Typha monoculture. However, the transition passed through a boundary consisting of several intermediate states before the Typha regime was reached. The slough-Typha boundary was physically defined by soil properties and vegetation. Within the boundary, a gradual change in surface water TP $(10-15 \mu \mathrm{g} / \mathrm{L})$ resulted from the changes in ecosystem state variables altering P cycling dynamics. This fundamentally differs from the Cladium-Typha shift described by Gunderson (2001). Despite the lack of an obvious trigger, we believe that the transition from slough to Typha is a regime shift (sensu Walker and
Meyers 2004) because dramatic nonlinear changes (i.e., thresholds) in soil and vegetation associated with a gradual increase in surface water TP occurred rapidly within a small spatial extent (boundary width $<500 \mathrm{~m}$ ).

Recently, Ries et al. (2004) derived a conceptual mechanistic model to describe changes in taxonomic patterns across community boundaries. Their model consists of four mechanisms: (1) ecological flows, (2) access to spatially separate resources, (3) resource mapping (organism distributions reflect resources), and (4) species interactions. Different pathways influence the distribution of sessile vs. mobile organisms; because the regime shifts in the Everglades are based on vegetation, we focus on the pathways that influence sessile organisms. Our conceptual model (Fig. 10) is that periphyton and macrophyte distributions are: (1) directly influenced by $\mathrm{P}$ supply, (2) mapped to the abiotic environment (soil P), and (3) directly affected by competition for resources. These processes are linked through a series of positive feedback loops directly influencing $\mathrm{P}$ dynamics that gives rise, in part, to the observed water column and soil $\mathrm{P}$ gradient in WCA-2A.

\section{Regime shift: slough-Typha}

There is a close coupling of dominant vegetation with BAFL and soil characteristics in sloughs. Sloughs with the lowest TP concentrations consisted of periphyton and low-organic (marl like) soils (Fig. 10A; periphyton box). The high-Ca soil content in "periphyton" sloughs is biologically regulated by the native periphyton assemblages composed of filamentous cyanobacteria (McCormick et al. 1996) capable of precipitating Ca (Gleason and Spackman 1974, Browder et al. 1994). 
TABLE 4. GMTP concentration at which a significant change point was detected in relation to BAFL, soil $(0-10 \mathrm{~cm})$, and Nymphaea leaf nutrient content, and BAFL TP concentration at which a significant change point was detected in relation to BAFL and Nymphaea leaf nutrient content.

\begin{tabular}{|c|c|c|c|c|c|c|}
\hline \multirow[b]{2}{*}{ Parameter } & \multicolumn{3}{|c|}{ Relationship to GMTP } & \multicolumn{3}{|c|}{ Relationship to BAFL TP } \\
\hline & $\begin{array}{l}\text { GMTP change } \\
\text { point }(\mu \mathrm{g} / \mathrm{L}) \dagger\end{array}$ & $\begin{array}{l}\text { Parameter mean } \\
\text { at change point }\end{array}$ & $P$ & $\begin{array}{c}\text { BAFL TP } \\
\text { change point }(\mathrm{mg} / \mathrm{kg}) \dagger\end{array}$ & $\begin{array}{l}\text { Parameter mean } \\
\text { at change point }\end{array}$ & $P$ \\
\hline \multicolumn{7}{|l|}{ BAFL } \\
\hline TP (mg/kg) & $\begin{array}{l}\leq 11 \\
>11\end{array}$ & $\begin{array}{r}442 \\
1004\end{array}$ & $<0.001$ & & & \\
\hline $\mathrm{Ca}(\mathrm{g} / \mathrm{kg})$ & $\begin{array}{l}\leq 11 \\
>11\end{array}$ & $\begin{array}{l}95 \\
33\end{array}$ & 0.003 & $\begin{array}{c}<226 \\
226-712 \\
>712\end{array}$ & $\begin{array}{r}178 \\
80 \\
32\end{array}$ & 0.001 \\
\hline TOC (g/kg) & $\begin{array}{l}\leq 11 \\
>11\end{array}$ & $\begin{array}{l}318 \\
407\end{array}$ & 0.008 & $\begin{array}{c}<226 \\
226-712 \\
>712\end{array}$ & $\begin{array}{l}191 \\
338 \\
410\end{array}$ & 0.005 \\
\hline Ash $(\%)$ & $\begin{array}{l}\leq 11 \\
>11\end{array}$ & $\begin{array}{l}33 \\
13\end{array}$ & 0.002 & $\begin{array}{c}<226 \\
226-712 \\
>712\end{array}$ & $\begin{array}{l}58 \\
29 \\
13\end{array}$ & 0.004 \\
\hline $\mathrm{TN}(\mathrm{g} / \mathrm{kg})$ & $\begin{array}{l}\leq 11 \\
>11\end{array}$ & $\begin{array}{l}27 \\
38\end{array}$ & $<0.001$ & $\begin{array}{c}<260 \\
260-792 \\
>792\end{array}$ & $\begin{array}{l}16 \\
30 \\
39\end{array}$ & 0.001 \\
\hline \multicolumn{7}{|l|}{ Soil $(0-10 \mathrm{~cm})$} \\
\hline TP $(\mathrm{mg} / \mathrm{kg})$ & $\begin{array}{l}\leq 9 \\
>9\end{array}$ & $\begin{array}{l}300 \\
478\end{array}$ & 0.05 & & & \\
\hline $\mathrm{Ca}(\mathrm{g} / \mathrm{kg})$ & $\begin{array}{l}\leq 12 \\
>12\end{array}$ & $\begin{array}{l}65 \\
31\end{array}$ & 0.08 & & & \\
\hline $\begin{array}{l}\text { TOC }(g / k g) \\
\text { Ash }(\%)\end{array}$ & $\begin{array}{l}\mathrm{NCPD} \\
\leq 12 \\
>12\end{array}$ & 24 & 0.08 & & & \\
\hline $\mathrm{TN}(\mathrm{g} / \mathrm{kg})$ & NCPD & & & & & \\
\hline \multicolumn{7}{|l|}{ Nymphaea leaf } \\
\hline $\mathrm{TP}(\mathrm{mg} / \mathrm{kg})$ & $\begin{array}{l}\leq 10 \\
>10\end{array}$ & $\begin{array}{r}966 \\
1180\end{array}$ & 0.04 & $\begin{array}{l}<700 \\
>700\end{array}$ & $\begin{array}{r}937 \\
1263\end{array}$ & 0.001 \\
\hline $\mathrm{TN}(\mathrm{g} / \mathrm{kg})$ & NCPD & & & $\begin{array}{l}<672 \\
>672\end{array}$ & $\begin{array}{l}23 \\
26\end{array}$ & 0.001 \\
\hline
\end{tabular}

Notes: Mean at change point reflects the average BAFL, soil, or leaf concentration associated with the GMTP or BAFL TP change point. Values in italics have a significant change point at a marginal $\alpha(0.05-0.10)$. NCPD indicates that no change point was detected.

$\dagger$ The change point is the concentration of the ecological driver (GMTP and BAFL TP) at which a difference in the mean concentration of the dependent variable (BAFL and soil TOC, Ca, ash, and TN; Nymphaea leaf TP and TN) is observed.

$\$$ The parameter mean change point is the mean concentration of the dependent variable above and below the change point.

Similar cyanobacteria mats and soils are prevalent in the low-P tropical freshwater marshes of northern Belize (Rejmánková and Komárková 2000, 2005). Experimental and observational studies have shown that mats from both wetlands rapidly disintegrate with low levels of $\mathrm{P}$ enrichment (McCormick and O'Dell 1996, McCormick et al. 2001, Rejmánková and Komárková 2005). The exact mechanism by which the mats disintegrate is unclear, but it is hypothesized to be a function of the mat's ability to assimilate $\mathrm{P}$, such that with increased $\mathrm{P}$ loading, the mass removal capacity per unit area that can be transformed or absorbed by the periphyton mat with no significant change in internal structure or function is exceeded (Richardson and Qian 1999, Buzzelli et al. 2000, Dong et al. 2002, Gaiser et al. 2004). Gaiser et al. (2004) suggest that when periphyton $\mathrm{P}$ exceeds $150 \mathrm{mg} / \mathrm{kg}$, the calcium-precipitating cyanobacteria are competitively displaced by other species. Although we did not measure periphyton $\mathrm{P}$, the change in average BAFL Ca content from 178 to $80 \mathrm{~g} / \mathrm{kg}$ associated with the low $226 \mathrm{mg} / \mathrm{kg}$ BAFL TP change point supports the periphyton $\mathrm{P}$ critical threshold proposed by Gaiser et al. (2004).

With the loss of periphyton production, macrophytes dominate sloughs, thus increasing organic carbon deposition (Fig. 10A; open marsh). In WCA-2A, open marshes are characterized by Eleocharis elongata and Eleocharis cellulosa (Vaithiyanathan and Richardson 1999, McCormick et al. 2002). We did not assess Eleocharis density, but it was a major feature of the sloughs that we studied (Fig. 2C). Below the GMTP threshold (11 $\mu \mathrm{g} / \mathrm{L}$; Fig. 9), the BAFL TP content averages $<442 \mathrm{mg} / \mathrm{kg}$ and probably reflects stable oligotrophic conditions because the flux of $\mathrm{P}$ from the soil is low (Fisher and Reddy 2001). Above the GMTP threshold, TOC and $\mathrm{P}$ content increases probably arise due to a positive feedback between higher rates of macrophyte, especially Eleocharis, production in response to the greater availability of $\mathrm{P}$ and higher rates of C turnover in BAFLs (DeBusk and Reddy 1998, Daoust and Childers 1999, Qualls and Richardson 2000, Macek and Rejmánková 2007). Open marshes, composed 

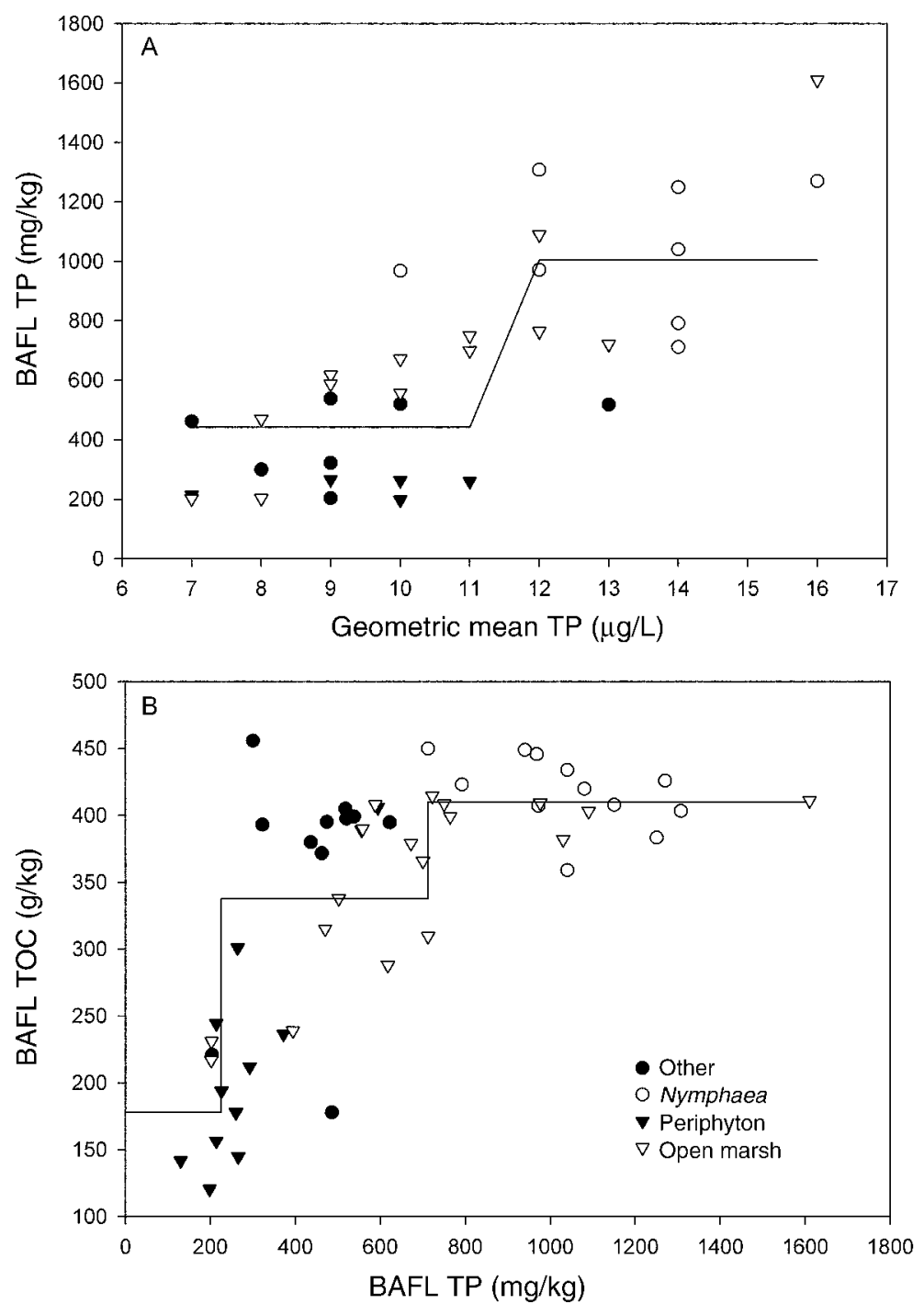

FIG. 9. Examples of change point diagrams for (A) the GMTP value at which a significant difference in BAFL TP was detected and (B) the BAFL TP value at which significant differences in BAFL TOC were detected. The change point model is indicated by the solid line $\left(r^{2}\right.$ for GMTP $=0.32 ; r^{2}$ for BAFL TP $\left.=0.71\right)$. Refer to Table 4 for more detail. Scatterplots are grouped according to the GIS vegetation classification.

mostly of Eleocharis, occur throughout much of the oligotrophic Everglades (Childers et al. 2003) and marshes in northern Belize (Johnson and Rejmánková 2005) and tend to be negatively related to soil $P$ (Vaithiyanathan and Richardson 1999, McCormick et al. 2002, Johnson and Rejmánková 2005). Vaithiyanathan and Richardson (1999) found that Eleocharis occurred frequently when soil TP (in the top $5 \mathrm{~cm}$ ) was $<500 \mathrm{mg} / \mathrm{kg}$, was occasional in sloughs when soil TP was $500-700 \mathrm{mg} / \mathrm{kg}$, and was rare or absent when soil TP was $>700 \mathrm{mg} / \mathrm{kg}$. Similarly, McCormick et al. (2002) reported that frequency of Eleocharis declined to less than $10 \%$ when soil TP $(0-10 \mathrm{~cm})$ was $>450 \mathrm{mg} / \mathrm{kg}$. Our results correspond closely in that the $95 \%$ confidence interval for open-marsh soil TP was between 262 and $384 \mathrm{mg} / \mathrm{kg}$. However, the range of TP for the overlying BAFL (floc) was much greater, ranging from 202 to $1610 \mathrm{mg} / \mathrm{kg}$. The differential between BAFL and soil TP suggests that $\mathrm{P}$ cycling in the BAFLs is much more dynamic than in the soils, but little is known about BAFL P dynamics.

Although it is a common macrophyte among all the sloughs surveyed, Nymphaea odorata showed a clear response with moderate $\mathrm{P}$ enrichment. Significantly greater leaf nutrients occurred when GMTP and BAFL TP exceeded $10 \mu \mathrm{g} / \mathrm{L}$ and $700 \mathrm{mg} / \mathrm{kg}$, respectively. Newman et al. (2004) experimentally demonstrated that Nymphaea leaf nutrient content was directly linked to increased TP loading. Concomitant with increased leaf nutrient levels was an increase in leaf size as P limitation was reduced. However, Nymphaea did not dominate sloughs until BAFL TP exceeded $859 \mathrm{mg} / \mathrm{kg}$ (Fig. 10A). 

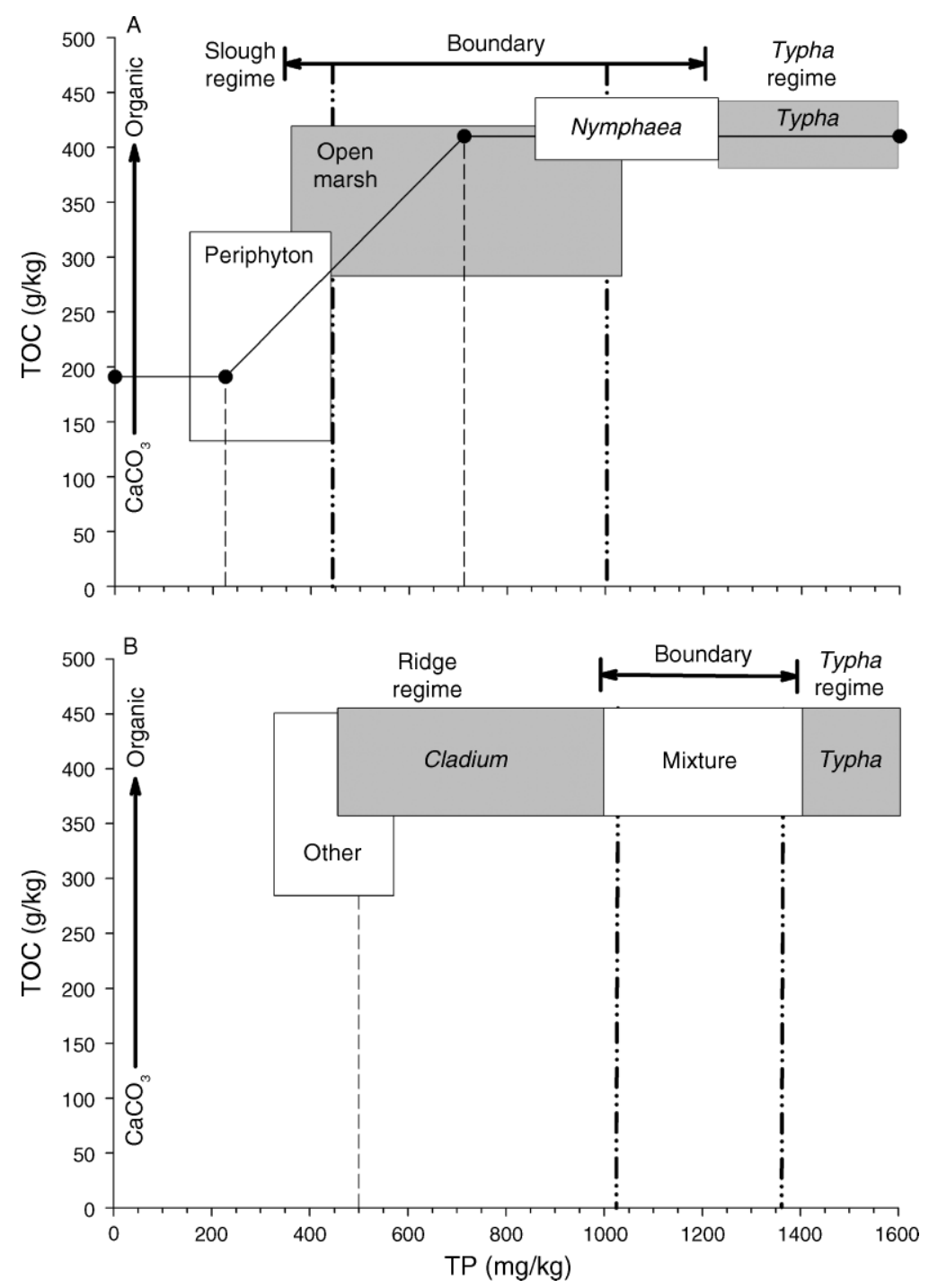

FIG. 10. Conceptual model of the (A) slough-Typha regime and (B) Cladium-Typha regime. The gray boxes represent the vegetation classification delineated by the upper and lower $95 \%$ confidence limits of TP $(\mathrm{mg} / \mathrm{kg})$ and TOC $(\mathrm{g} / \mathrm{kg})$ for each class. The thin vertical dashed lines indicate the critical threshold for BAFL TP (black circles) linked to the mean TOC value (solid lines). The vertical dashed-double dotted lines are the mean BAFL TP values associated with the GMTP critical threshold of $11 \mu \mathrm{g} / \mathrm{L}$. The boundary is defined as the lower and upper 95\% confidence interval for the two groups.

This suggests that Nymphaea outcompeted other slough vegetation (e.g., Eleocharis). Leaf N:P (molar) greater than 36 and less than 30 is indicative of $\mathrm{P}$ and $\mathrm{N}$ limitation, respectively, in Nymphaea (Koerselman and Meuleman 1996, Newman et al. 2004). Although we observed a decline in leaf $\mathrm{N}: \mathrm{P}$ with higher $\mathrm{P}$, ratios were greater than 40 , suggesting that Nymphaea remained $\mathrm{P}$ limited.

The Nymphaea sloughs just described reflect the slough end member since Typha invaded the sloughs, which resulted in their loss from the landscape (Figs. 2D and 10A; see Plate 1). The soil TP 95\% confidence interval for Nymphaea sloughs (441-783 mg/kg) was much greater than for open-marsh sloughs (262-384 $\mathrm{mg} / \mathrm{kg}$ ) but, more importantly, corresponds to observed patterns of soil TP and Typha density. The occurrence of Typha in WCA-2A is low when soil TP $(0-10 \mathrm{~cm})$ is less than $600 \mathrm{mg} / \mathrm{kg}$, is more prevalent between 600 and 750 $\mathrm{mg} / \mathrm{kg}$, and dominates when soil TP exceeds $1050 \mathrm{mg} / \mathrm{kg}$ (Vaithiyanathan and Richardson 1999, McCormick et al. 2002). The soil TP in dense Typha stands in the Belizean marshes is also similar to the concentrations observed in the Everglades (Johnson and Rejmánková 2005).

We can quantitatively define the boundary associated with the regime shift using the lower and upper $95 \%$ confidence intervals associated with mean BAFL TP (Fig. 10A; dashed-dotted lines) below and above the GMTP change point of $11 \mu \mathrm{g} / \mathrm{L}$. Thus, the boundary is conservatively defined as BAFL TP concentrations 
between 345 and $1250 \mathrm{mg} / \mathrm{kg}$ (Fig. 10A; Boundary). Above and below the boundary represents the stable eutrophic and oligotrophic regimes. The boundary represents a highly dynamic, nonlinear region in which the loss of ecosystem resilience is a direct response to eutrophication. This is evident by the shift from sloughs dominated by calcareous periphyton, to organic openmarsh sloughs, to Nymphaea sloughs, to Typha. Many studies have shown that ecological processes differ between what we term the slough regime (unenriched) and Typha regime (enriched); see the Appendix. Unfortunately, these studies were not conducted within the boundary and thus do not adequately or accurately reflect the "transition" zone between the two regimes.

The role of hydrology in regulating community structure was not directly addressed in this study. The similarity among periphyton, open-marsh, and $\mathrm{Nym}$ phaea class water depths (Table 3), along with their close proximity to one another, suggest that the sloughs experienced a similar hydroperiod. Typha and Eleocharis growth rates are positively related to water depth (Newman et al. 1996, Busch et al. 2004). We suspect that the rate of the slough-Typha regime shift, while driven primarily by $\mathrm{P}$, is also influenced by regional hydrologic processes (e.g., floods and droughts). We do not know if disturbance events like these function as triggers or as a mechanism regulating the rate of change.

\section{Regime shift: Cladium-Typha}

Sloughs classified as "other" were not true sloughs but were small openings on Cladium ridges and, when coupled with the gradient study (Figs. 3 and 4), can be used to define the Cladium-Typha regime shift (Fig. 10B). The small "other" openings occurred below the 11 $\mu \mathrm{g} / \mathrm{L}$ GMTP critical threshold (Fig. 9A) and were not a feature of the landscape when BAFL and soil TP exceeded 444 and $374 \mathrm{mg} / \mathrm{kg}$, respectively. These soil values are typical of sparse Cladium ridges in the unenriched Everglades (DeBusk et al. 1994, Craft and Richardson 1997, Vaithiyanathan and Richardson 1999, Childers et al. 2003) and marshes in northern Belize (Johnson and Rejmánková 2005). Cladium biomass increases in response to eutrophication but remains dominant until floc and soil TP values exceed 800 $\mathrm{mg} / \mathrm{kg}$, as shown in this study and others (Davis 1991, Doren et al. 1997, Miao and DeBusk 1999, McCormick et al. 2002, Childers et al. 2003). Cladium and Typha coexist until floc and soil TP values exceed 1600 and $1100 \mathrm{mg} / \mathrm{kg}$, respectively, after which a Typha monoculture dominates. The likelihood of a disturbance triggering a regime shift is greater when floc and soil TP values are $800 \mathrm{mg} / \mathrm{kg}$, because Typha has a high $\mathrm{P}$ demand. This suggests there is a decoupling between the protective critical surface water TP threshold and corresponding floc TP value (Fig. 10B; dashed line) with the observed regime shift from Cladium to Typha (Fig. 10B; dash-dotted line).

\section{Conclusions}

Eutrophication is a widespread disturbance that threatens many wetlands (Brinson and Malvárez 2002). The replacement of the diverse indigenous vegetation community with one composed of relatively few invasive species, such as Typha, is a commonality shared among many wetlands experiencing nutrient enrichment (Galatowitsch et al. 1999, Brinson and Malvárez 2002). For example, nutrient enrichment has caused the expansion of Typha and has elevated soil nutrients in many North American temperate wetlands (Galatowitsch et al. 1999, Woo and Zedler 2002, Craft et al. 2007), in the tropical freshwater marshes in Belize (Rejmánková 2001, Johnson and Rejmánková 2005), and in other regions of the Everglades (Doren et al. 1997, Newman et al. 1998, Childers et al. 2003). There is not enough information for us to definitively state whether these vegetation shifts occur gradually or suddenly (i.e., regime shift), but we suspect that regime shifts similar to that described here for WCA-2A are more the norm than the exception. The gradient studies of Childers et al. (2003) provide support for the regime shift concept in other regions of the Everglades, where nonlinear declines in Typha and soil $\mathrm{P}$ were observed from sources of $\mathrm{P}$ discharge in WCA-1, WCA-3A, and Everglades National Park. Likewise, strong relationships between vegetation distributions and soil $\mathrm{P}$ are evident in marshes in Northern Belize, which are very similar floristically and chemically to the Everglades (Rejmánková 2001, Johnson and Rejmánková 2005).

Folke et al. (2004) argue that in order to sustain or restore a desired ecosystem state, an active adaptive management approach that governs for resilience is essential. This requires knowledge of (1) the critical threshold for the controlling variable and (2) the current ecosystem state relative to the threshold. Such information is best obtained by studying the boundary between the regimes. Our results suggest that the oligotrophic Everglades comprises at least two low-nutrient stability regimes: Cladium ridges and open-water sloughs. Eutrophication has eroded the resilience of these regimes, which has resulted in a sudden shift to a high-nutrient stability regime composed of Typha. More importantly, Cladium ridge and slough regimes respond independently and differently to eutrophication. When put in the critical attribute context of Folke et al. (2004), the extremely low surface water $\mathrm{P}$ and soil $\mathrm{P}$ thresholds suggest that both regimes are poised close to the thresholds (i.e., low precariousness). Changes in the independent ecosystem state variables (vegetation) within sloughs across the boundary indicate that the slough regime has a lower ability to absorb (latitude) and resist (resistance) eutrophication than the Cladium regime, which exhibited only one vegetation shift.

The current management strategy for reducing Everglades eutrophication (i.e., sustaining resilience) is to return water column TP concentrations closer to the $10 \mu \mathrm{g} / \mathrm{L}$ threshold by reducing $\mathrm{P}$ loads. The reduction in 
P loads is attained by implementation of best management practices (BMP) and by passing P-rich agricultural and urban runoff through large constructed wetlands called stormwater treatment areas, STA (see Sklar et al. 2005). To restore the boundary or Typha regime back to the desired ridge and slough regime is much more difficult because of the resilience inherent in the Typha regime and the degree of effort required to move BAFL TP concentrations below the critical threshold values. This may occur naturally with the implementation of $\mathrm{P}$ load reduction (i.e., cleaner water) or through planned management activities that reduce the availability of $P$. However, restoration requires not only an accurate determination of the $\mathrm{P}$ load that the low-nutrient stability regimes can absorb (i.e., assimilative capacity or latitude) without shifting regimes, but also an understanding of how to apply the load. Currently, estimates of the amount of $\mathrm{P}$ that the Everglades can assimilate without detrimental effects range from $<0.6 \mathrm{~g} \cdot \mathrm{m}^{-2} \cdot \mathrm{yr}^{-1}$ (McCormick and O'Dell 1996) to $1.0 \mathrm{~g} \cdot \mathrm{m}^{-2} \cdot \mathrm{yr}^{-1}$ (Richardson and Qian 1999) and are the topic of much debate. Nonetheless, restoration will benefit from using an adaptive management approach. Our results suggest that in order to achieve the desired goals of abating Typha expansion and restoring the Everglades, focus should be given to the boundary between the slough and Typha regime. To do this, it is necessary to develop monitoring approaches to assess whether ecosystem resilience of the low-nutrient stability regime is improving (Groffman et al. 2006).

\section{ACKNOWLEDGMENTS}

We thank Robert B. E. Shuford III, Debra Kilbane, Michael Manna, and Andrew Gottlieb for assistance in the field. Mike Chimney, Carl Fitz, and two anonymous reviewers provided valuable comments. We also thank the SFWMD pilots K. J. Wells and Bob Flatman for flight support, as well as the pilots Gary Hanson and Terry Jones of Air Coastal Helicopters.

\section{Literature Cited}

Brinson, M. M., and A. I. Malvárez. 2002. Temperate freshwater wetlands: types, status, and threats. Environmental Conservation 29:115-133.

Browder, J. A., P. J. Gleason, and D. R. Swift. 1994 Periphyton in the Everglades: spatial variation, environmental correlates, and ecological implications. Pages 379-418 in S. M. Davis and J. C. Ogden, editors. Everglades: the ecosystem and its restoration. St. Lucie Press, Delray Beach, Florida, USA.

Bruland, G. L., T. Z. Osbourne, K. R. Reddy, S. Grunwald, S. Newman, and W. F. DeBusk. 2007. Recent changes in soil total phosphorus in the Everglades: Water Conservation Area 3. Environmental Monitoring and Assessment 129:379395.

Busch, J., I. A. Mendelssohn, B. Lorenzen, H. Brix, and S. Miao. 2004. Growth responses of the Everglades wet prairie species Eleocharis cellulosa and Rhynchospora tracyi to water level and phosphate availability. Aquatic Botany 78:37-54.

Buzzelli, C. P., D. L. Childers, Q. Dong, and R. D. Jones. 2000. Simulation of periphyton dynamics in Everglades National Park. Ecological Modelling 134:103-115.

Carpenter, S. R. 2005. Eutrophication of aquatic ecosystems: bistability and soil phosphorus. Proceedings of the National Academy of Sciences (USA) 102:10002-10005.
Chen, J., and A. K. Gupta. 2000. Parametric statistical change point analysis. Birkhauser, Boston, Massachusetts, USA.

Childers, D. L., R. F. Doren, R. D. Jones, G. B. Noe, M. Rugge, and L. J. Scinto. 2003. Decadal change in vegetation and soil phosphorus pattern across the Everglades landscape. Journal of Environmental Quality 32:344-362.

Craft, C. B., K. Krull, and S. Graham. 2007. Ecological indicators of nutrient enrichment, freshwater wetlands, Midwestern United States (U.S.). Ecological Indicators 7: 733-750.

Craft, C. B., and C. J. Richardson. 1997. Relationships between soil nutrients and plant species composition in Everglades peatlands. Journal of Environmental Quality 26:224-232.

Cressie, N. A. C. 1991. Statistics for spatial data. John Wiley, New York, New York, USA.

Daoust, R. J., and D. L. Childers. 1999. Controls of emergent macrophyte composition, abundance, and productivity in freshwater Everglades wetland communities. Wetlands 19: 262-275.

Davis, S. M. 1991. Growth, decomposition, and nutrient retention of Cladium jamaicense Crantz and Typha domingensis Pers. in the Florida Everglades. Aquatic Botany 40:203-224.

Davis, S. M. 1994. Phosphorus inputs and vegetation sensitivity in the Everglades. Pages 357-378 in S. M. Davis and J. C. Ogden, editors. Everglades: the ecosystem and its restoration. St. Lucie Press, Delray Beach, Florida, USA.

Davis, S. M., and J. C. Ogden, editors. 1994. Everglades: the ecosystem and its restoration. St. Lucie Press, Delray Beach, Florida, USA.

DeBusk, W. F., S. Newman, and K. R. Reddy. 2001. Spatiotemporal patterns of soil phosphorus enrichment in Everglades Water Conservation Area 2A. Journal of Environmental Quality 20:1438-1446.

DeBusk, W. F., and K. R. Reddy. 1998. Turnover of detrital carbon in a nutrient-impacted Everglades marsh. Soil Science Society of America Journal 62:1460-1468.

DeBusk, W. F., K. R. Reddy, M. S. Koch, and Y. Wang. 1994. Spatial distribution of soil nutrients in a northern Everglades marsh: Water Conservation Area 2A. Soil Science Society of America Journal 58:543-552.

Dong, Q., P. V. McCormick, F. H. Sklar, and D. L. DeAngelis. 2002. Structural instability, multiple stable states, and hysteresis in periphyton driven by phosphorus enrichment in the Everglades. Theoretical Population Biology 61:1-13.

Doren, R. F., T. V. Armentano, L. D. Whiteaker, and R. D. Jones. 1997. Marsh vegetation patterns and soil phosphorus gradients in the Everglades ecosystem. Aquatic Botany 56: 145-163.

Fisher, M. M., and K. R. Reddy. 2001. Phosphorus flux from wetland soils affected by long-term nutrient loading. Journal of Environmental Quality 30:261-271.

Folke, C., S. R. Carpenter, B. Walker, M. Scheffer, T. Elmqvist, L. H. Gunderson, and C. S. Holling. 2004. Regime shifts, resilience, and biodiversity in ecosystem management. Annual Review of Ecology and Systematics 35:557-581.

Gaiser, E. E., L. J. Scinto, J. H. Richards, K. Jayachandran, D. L. Childers, J. C. Trexler, and R. D. Jones. 2004. Phosphorus in periphyton mats provides the best metric for detecting low-level P enrichment in an oligotrophic wetland. Water Research 38:507-516.

Galatowitsch, S. M., N. O. Anderson, and P. D. Ascher. 1999. Invasiveness in wetland plants in temperate North America. Wetlands 19:733-755.

Gleason, P. J., and W. Spackman. 1974. Calcareous periphyton and water chemistry in the Everglades. Pages 146-181 in P. J. Gleason, editor. Environments of South Florida: present and past II. Miami Geological Society, Coral Gables, Florida, USA. 
Groffman, P. M., et al. 2006. Ecological thresholds: the key to successful environmental management or an important concept with no practical application? Ecosystems 9:1-13.

Gunderson, L. H. 2001. Managing surprising ecosystems in southern Florida. Ecological Economics 37:371-378.

Gunderson, L. H., and L. Pritchard, Jr., editors. 2002. Resilience and the behavior of large-scale ecosystems. Island Press, Washington, D.C., USA.

Holling, C. S. 1973. Resilience and stability of ecological systems. Annual Review of Ecology and Systematics 4:1-23.

Johnson, S., and E. Rejmánková. 2005. Impacts of land use on nutrient distribution and vegetation composition of freshwater wetlands in northern Belize. Wetlands 25:89-100.

Koerselman, W., and A. F. M. Meuleman. 1996. The vegetation N:P ratio: a new tool to detect the nature of nutrient limitation. Journal of Applied Ecology 33:14411450 .

Light, S. S., and J. W. Dineen. 1994. Water control in the Everglades: a historical perspective. Pages $47-84$ in S. M. Davis and J. C. Ogden, editors. Everglades: the ecosystem and its restoration. St. Lucie Press, Delray Beach, Florida, USA.

Macek, P., and E. Rejmánková. 2007. Response of emergent macrophytes to experimental nutrient and salinity additions. Functional Ecology 21:478-488.

Manly, B. J. F., and R. I. C. Francis. 2002. Testing for mean and variance differences with samples from distributions that may be non-normal with unequal variances. Journal of Statistical Computing and Simulation 72:633-646.

McCormick, P. V., S. Newman, S. Miao, D. E. Gawlik, D. Marley, K. R. Reddy, and T. D. Fontaine. 2002. Effects of anthropogenic phosphorus inputs on the Everglades. Pages $83-126$ in J. W. Porter and K. G. Porter, editors. The Everglades, Florida Bay, and coral reefs of the Florida Keys: an ecosystem sourcebook. CRC Press, Boca Raton, Florida, USA.

McCormick, P. V., and M. B. O’Dell. 1996. Quantifying periphyton responses to phosphorus in the Florida Everglades: a synoptic-experimental approach. Journal of the North American Benthological Society 15:450-468.

McCormick, P. V., M. B. O'Dell, R. B. E. Shuford III, J. B. Backus, and W. C. Kennedy. 2001. Periphyton responses to experimental phosphorus enrichment in a subtropical wetland. Aquatic Botany 71:119-139.

McCormick, P. V., P. S. Rawlik, K. Lurding, E. P. Smith, and F. H. Sklar. 1996. Periphyton-water quality relationships along a nutrient gradient in the northern Florida Everglades. Journal of the North American Benthological Society 15: 433-449.

Miao, S., and W. F. DeBusk. 1999. Effects of phosphorus enrichment on structure and function of sawgrass and cattail communities in the Everglades. Pages $275-300$ in K. R. Reddy, G. A. O'Connor, and C. L. Schelske, editors. Phosphorus biogeochemistry in subtropical ecosystems. Lewis Publishers, Boca Raton, Florida, USA.

Newman, S., J. B. Grace, and J. W. Koebel. 1996. Effects of nutrients and hydroperiod on Typha, Cladium, and Eleocharis: implications for Everglades restoration. Ecological Applications 6:774-783.

Newman, S., P. V. McCormick, S. Miao, J. A. Laing, W. C. Kennedy, and M. B. O'Dell. 2004. The effect of phosphorus enrichment on the nutrient status of a northern Everglades slough. Wetlands Ecology and Management 12:63-79.

Newman, S., J. Schutte, J. B. Grace, K. Rutchey, T. D. Fontaine, K. R. Reddy, and M. Pietrucha. 1998. Factors influencing cattail abundance in the northern Everglades. Aquatic Botany 60:265-280.

Porter, J. W., and K. G. Porter, editors. 2002. The Everglades, Florida Bay, and coral reefs of the Florida Keys: an ecosystem sourcebook. CRC Press, Boca Raton, Florida, USA.

Qualls, R. G., and C. J. Richardson. 2000. Phosphorus enrichment affects litter decomposition, immobilization, and soil microbial phosphorus in wetland mesocosms. Soil Science Society of America Journal 64:799-808.

Rejmánková, E. 2001. Effect of experimental phosphorus enrichment on oligotrophic tropical marshes in Belize, Central America. Plant and Soil 236:33-53.

Rejmánková, E., and J. Komárková. 2000. A function of cyanobacterial mats in phosphorus-limited tropical wetlands. Hydrobiologia 431:135-153.

Rejmánková, E., and J. Komárková. 2005. Response of cyanobacterial mats to nutrient and salinity changes. Aquatic Botany 83:87-107.

Richardson, C. J., and S. S. Qian. 1999. Long-term phosphorus assimilative capacity in freshwater wetlands: a new paradigm for sustaining ecosystem structure and function. Environmental Science and Technology 33:1545-1551.

Ries, L., J. Fletcher, J. Robert, J. Battin, and T. D. Sisk. 2004. Ecological responses to habitat edges: mechanisms, models, and variability explained. Annual Review of Ecology and Systematics 35:491-522.

Rutchey, K., et al. 2006. Vegetation classification for South Florida Natural Areas. USGS Open File Report 2006-1240, Saint Petersburg, Florida, USA.

Rutchey, K., T. Schall, and F. Sklar. In press. Development of a Water Conservation Area-2A vegetation map for Everglades restoration. Wetlands.

Rutchey, K., L. Vilchek, and M. Love. 2005. Development of a vegetation map for Water Conservation Area 3. Technical Publication ERA Number 421. South Florida Water Management District, West Palm Beach, Florida, USA.

Scheffer, M., and S. R. Carpenter. 2003. Catastrophic regime shifts in ecosystems: linking theory to observation. Trends in Ecology and Evolution 18:648-656.

Sklar, F. H., et al. 2005. The ecological-societal underpinnings of Everglades restoration. Frontiers in Ecology and the Environment 3:161-169.

Vaithiyanathan, P., and C. J. Richardson. 1999. Macrophyte species changes in the Everglades: examination along a eutrophication gradient. Journal of Environmental Quality 28:1347-1358

Walker, B., and J. A. Meyers. 2004. Thresholds in ecological and social-ecological systems: a developing database. Ecology and Society 9(2):15. 〈http://www.ecologyandsociety.org/ vol9/iss $2 / \operatorname{art} 15 /\rangle$

Woo, I., and J. B. Zedler. 2002. Can nutrients alone shift a sedge meadow towards dominance by the invasive Typha $\times$ Glauca? Wetlands 22:509-521.

\section{APPENDIX}

Table of ecological process type studies performed along the nutrient gradient in Water Conservation Area 2A illustrating that they all compare oligotrophic vs. eutrophic conditions and thus do not capture the dynamics in the "boundary" of rapid ecological change (Ecological Archives M078-022-A1). 